Pamiętnik Literacki 2021, 1, s. 171-217

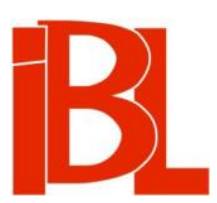

\title{
Profesor Stefania Skwarczyńska. Subiektywna próba biografii
}

Grzegorz Gazda 


\title{
PROFESOR STEFANIA SKWARCZYŃSKA SUBIEKTYWNA PRÓBA BIOGRAFII
}

\author{
W 75-lecie Katedry Teorii Literatury \\ Uniwersytetu Łódzkiego (1945-2020)
}

Kiedy rozpoczynałem studia na łódzkiej polonistyce, niewiele wiedziałem o uniwersyteckiej edukacji, o programach i o wykładowcach, z którymi miałem się w przyszłości zetknąć. Z jednym wyjątkiem. O Profesor Stefanii Skwarczyńskiej (19021988) słyszeliśmy wszyscy, głównie od licealnych polonistek; w ich opowieściach było więcej emocji i adoracji niż racjonalnych faktów i informacji przydatnych przyszłym studentom.

Debiutując w roli studentów, czekaliśmy pewnego październikowego popołudnia 1961 r. w auli nazywanej „akwarium” (ze względu na jedna ścianę przeszkloną dużymi oknami), usytuowanej na parterze biblioteki uniwersyteckiej przy ul. Matejki, na nasz pierwszy wykład z Panią Profesor, zatytułowany Wstęp do nauki o literaturze. Siedzieliśmy podekscytowani intuicjami, że oto właśnie dziś dokona się w nas przemiana $z$ nieco zahukanych jeszcze licealistów w studentów z prawdziwego zdarzenia. Stawiliśmy się na przedwieczornym dwugodzinnym wykładzie w 120-osobowym komplecie. Za oknami zmierzchało, a w auli paliły się już świetlówki, które przygasały i migotały, jakby sposobiły atmosferę godną studenckiej premiery.

Gdy stuknęły drzwi z tyłu sali, odwróciliśmy się wszyscy jednocześnie i zerwali $z$ miejsc - w drzwiach stanęła nieco pochylona, wsparta na lasce Pani Profesor. Po chwili wyprostowała się i zaczęła iść, lekko utykając ku podestowi $z$ katedrą. Układ auli był taki, że musiała przejść przez nią całą wzdłuż rzędów krzeseł i naszych szeregów. Popatrywała na nas $z$ ciekawościa i delikatnym uśmiechem. $Z$ upiętymi siwiejącymi włosami (dziś wiem, że nie miała wówczas jeszcze 60 lat), z niesfornymi kosmykami, które opadały na czoło, ubrana w szara sukienkę, $z$ fioletowym szalem na szyi, szła przez aulę kilkanaście chwil. Zatrzymała się przed podestem i skinęła ręka. Wtedy, przywróciwszy wstrzymany oddech, zaczęliśmy siadać najciszej jak można. Pani Profesor nie weszła na podest z katedrą. Stanęła przed nami, przed pierwszym rzędem słuchaczy, przysuwając sobie jedno z krzeseł, o które oparła laskę. W ręku trzymała dwie, trzy nieduże kartki, na które spojrzała, założywszy na moment okulary.

Tak zaczął się nasz pierwszy prawdziwie akademicki wykład. Akademicki, bo też i niełatwy. Chłonęliśmy każde słowo. Próbowaliśmy zapisywać każde zdanie, choć ze względu na treść nie było to proste. Pani Profesor mówiła niespiesznie, akcentując wszystkie istotne sformułowania, a niekiedy je powtarzając. Dzięki dobrej akustyce auli mogła posłużyć się całym rejestrem retorycznych tonacji. 
Wydobywała w swojej wypowiedzi wszelkie akcenty logiczne i niuanse poznawcze. Modulowała ich dźwiękowy zakres tak, jakby nie była to relacja na temat podstaw teoretycznych literaturoznawstwa, tylko jakaś fabularna, pełna dramatyzmu opowieść.

Wykład ten tyleż nas onieśmielał, co zaskakiwał nieznanymi terminami i definicjami, nie wszystkie przecież rozumieliśmy, a sensu niektórych trzeba było się domyślać, ale słuchaliśmy jak zahipnotyzowani, pewnie także aurą wieczoru, iście scenicznym monologiem Pani Profesor i świadomością, że oto uczestniczymy w niezwykłym wtajemniczeniu w wiedzę o sztuce literackiej. To przeświadczenie towarzyszyło mi przez całe studia w czasie wykładów i seminariów z Panią Profesor.

Tak było też w ciagu moich prawie 50 lat pracy w Katedrze Teorii Literatury, utworzonej dla Stefanii Skwarczyńskiej na Uniwersytecie Łódzkim i kierowanej przez nią od r. 1945 aż do przejścia na emeryturę w 1973 roku. Jak się dowiedziałem potem, była to pierwsza w Polsce katedra naukowa o profilu teoretycznoliterackim, co często Pani Profesor $z$ dumą podkreślała. Kiedyś nawet napisała do redakcji „Tekstów” interwencyjny list ze sprostowaniem - było to po tym, jak w jednym z numerów świętowano historię i jubileusz „pierwszej” placówki o takiej nazwie, powołanej przez Kazimierza Budzyka na Uniwersytecie Warszawskim przecież dopiero 10 lat później, bo w 1955 roku.

Ostateczny kształt organizacyjny katedry z trzema zakładami: literaturoznawczym, filmoznawczym i teatrologicznym, Pani Profesor nazwała na Kongresie Kultury w r. 1966 „eksperymentem łódzkim”, czyli swoistą integracją sztuki literackiej, teatralnej i filmowej w badaniach naukowych i dydaktyce. Tę ideę opracowała i rozpisała szczegółowo w notatkach i schematycznych tabelach na przełomie lat sześćdziesiątych i siedemdziesiątych, co zresztą nie przybrało kształtu organizacyjnego i było realizowane stopniowo, tylko w swoim ogólnym zarysie, w miare jak przyrastała liczba pracowników, asystentów i doktorantów, jak kształtowała się tematyka doktoratów i habilitacji, jak rysowały się możliwości tworzenia nowych zakładów i pracowni. W tych projektach zostały opisane także nader szczegółowo zakresy obowiązków naukowych i organizacyjnych wszystkich ówczesnych pracowników katedry.

Na innych uniwersytetach podobne placówki filmoznawcze i teatrologiczne zaczęły powstawać w nieodległej przyszłości, co w dalszych latach - jak sądzę, bo byłem tego aktywnym świadkiem - zrodziło studia kulturoznawcze w Polsce i dzięki czemu kulturoznawstwo jako dziedzina dydaktyki i odrębnych badań naukowych zyskało autonomiczny status [na krótko; w 2018 r. na miejscu kulturoznawstwa pojawiła się inna dyscyplina: nauki o kulturze i religii - przypis redakcji]. Na Uniwersytecie Łódzkim Katedrę Teorii Literatury, Teatru i Filmu przemieniliśmy potem w Instytut (1973) i przekształciliśmy ostatecznie, za mojej dyrektury, w r. 2011, w Instytut Kultury Współczesnej z trzema katedrami, ze swoistymi obszarami badań literaturoznawczych, filmoznawczo-medialnych i teatrologicznych. Powołano wtedy w strukturach Polskiej Akademii Nauk odpowiedni Komitet Nauk o Kulturze (2004), którego członkiem byłem przez dwie kadencje. Inni samodzielni pracownicy łódzkiego instytutu wciąż aktywnie działają w tym komitecie. I już tylko wspomnę, że w 2002 r. powstało także Polskie Towarzystwo Kulturoznawcze z reprezentacja badaczy z całej Polski. 
Wydział Filologiczny - wracając do czasów, kiedy zaczynałem studia - miał swoje siedziby rozrzucone po łódzkim śródmieściu. Przy Narutowicza znajdowały się rektorat i dziekanaty, na Lindleya odbywały się lektoraty i niektóre ćwiczenia, na Buczka - wykłady, bo tam, w budynku Wydziału Filozoficzno-Historycznego, znajdowały się sale, które na zajęciach z gramatyki opisowej, historii literatury i historii Polski mogły pomieścić cały nasz bardzo liczny rok. W al. Kościuszki sytuowały się zaś inne gmachy wynajmowane przez uczelnię.

Katedra Teorii Literatury ze swoimi trzema zakładami: Zakładem Teorii Literatury, Zakładem Wiedzy o Filmie (powstał w r. 1959; po latach uzupełniono jego nazwę o człon „i Telewizji”) oraz Zakładem Dramatu i Teatru (ten istnieje od r. 1969), podobnie jak katedry historycznoliterackie, mieściła się w bocznej części Biblioteki Uniwersytetu Łódzkiego, nowoczesnego i przestronnego budynku przy rogu Narutowicza i Matejki, powstałego w drugiej połowie lat pięćdziesiątych. Teraz znacznie przebudowany i powiększony, wciąż zaleca się niebanalną architekturą projektu Edmunda Orlika.

Lubiliśmy ten gmach ze względu na jego przyjazne wielopiętrowe przestrzenie ogromny hol (gdzie odbywały się rozmaite wystawy i prezentacje), podwójną salę z katalogami, dwie duże czytelnie, ogólną i czasopism, skomunikowane z magazynami w wielopiętrowym wieżowcu. A także ze względu na usytuowaną w podziemiach kafejkę, w której przesiadywaliśmy między zajęciami i lekturowymi obowiązkami w bibliotece. Piwniczka, nazywana czule „Piekiełkiem”, pełna dymu (wówczas wszyscy palili na potęgę), gwaru, śmiechu i żartów, uosabiała styl studenckiego życia, które wiosną i latem częściowo przenosiło się do parku im. Jana Matejki po drugiej stronie ulicy. Tam w dłuższych przerwach między zajęciami wspólnie czytaliśmy zadane artykuły, przepytywaliśmy się z SCS-u, czyli gramatyki języka staro-cerkiewno-słowiańskiego, i przygotowywali do egzaminów.

Nie będe się o swoich studenckich latach rozpisywał, bo temat tu - zgodnie $z$ tytułem - jest inny. Najkrócej mogę powiedzieć, że moje studia przebiegały zgodnie $\mathrm{z}$ akademickim kalendarzem i przewidzianymi powinnościami, zreszta pilnie wykonywanymi, o czym świadczył indeks, teraz przechowywany pieczołowicie w domowym archiwum. A tym 5 latom należałby się oddzielny, niemały tekst, bo „moje uniwersytety” - aby posłużyć się cytatem - nie dość, że bardzo dobrze wspominam we wszystkich zakresach, to muszę najwyraźniej powiedzieć, że do dziś tamte lata przechowuję w pamięci bez uszczerbku. Przywołują same pozytywne doświadczenia, ale i życzliwą sympatię, nierzadko przyjaźń ludzi, których wtedy spotykałem, których kochałem i którzy byli wsparciem dla mnie w ważnych momentach życia.

Oceny w indeksie miałem na ogół dobre i bardzo dobre, $z$ jednym wyjątkiem. Przy wykładzie $z$ historii literatury oświecenia rubryka na ocenę została pusta do końca studiów, a więc i do dziś. Wykład ten bojkotowałem, zreszta podobnie jak kilkanaście innych osób. Profesor czytał go mozolnie i monotonnie ze szkolnego zeszytu, w którym ów wykład zapisał, i prawdopodobnie powtarzał od lat, bo zeszyt wyglądał nieświeżo. Szkoda było na to czasu, bo przecież bez trudu dało się znaleźć całkiem dobre książki na temat polskiego oświecenia. Rok zatem zaliczyłem „warunkowo", oświecenie poznałem jak należy, ale bez obowiązkowego wykładu. Ów profesor nawet ogłosił dla nieobecnych amnestię i obiecał podpis w indeksie, jeśli 
tylko zgłoszą się na rozmowę sprawdzająca. Nie poddałem się. Egzamin z oświecenia zdałem u innego profesora. A i tak, mimo tej luki w indeksie, stałem się potem przez dwa lata beneficjentem stypendium naukowego.

Na ostatnim roku studiów, w styczniu 1966, byłem świadkiem uroczystości 40-lecia pracy naukowej prof. Skwarczyńskiej, jubileuszu liczonego od daty uzyskania przez nią doktoratu na Wydziale Humanistycznym Uniwersytetu Jana Kazimierza we Lwowie (do 1 IX 1924 był to Wydział Filozoficzny) w r. 1925 pod kierunkiem Juliusza Kleinera (1886-1957) z drukowaną rozprawą Ewolucja obrazów u Słowackiego. Habilitację zdobyła Stefania Skwarczyńska w 1937 r. na podstawie książki Teoria listu, pierwszej dysertacji z zakresu teorii literatury, poświęconej literaturze stosowanej (termin stworzony przez habilitantkę). Inni jej profesorowie $z$ lat studiów to Wilhelm Bruchnalski (1859-1938), Kazimierz Twardowski (1866-1938), Edward Porębowicz (1862-1937), Zygmunt Czerny (1888-1975), Jan Kasprowicz (1860-1926) i Tadeusz Lehr-Spławiński (1891-1965). Ewolucja obrazów u Stowackiego to napisana przez 23-letnią Skwarczyńską po drugim roku studiów praca zaliczeniowa, która uzyskała tak wysoką ocenę Kleinera, że uznał ją on za podstawę do doktoratu (i zakwalifikował do wydania, jako pierwszej pozycji, w uruchomionej przez siebie serii naukowej „Badania Literackie”). Równie błyskotliwa była habilitacja po licznych publikacjach kandydatki do docentury m.in. na temat twórczości Juliusza Słowackiego i Adama Mickiewicza. I w tym przypadku Kleiner, najwybitniejszy badacz dzieł obu wielkich romantyków, oceniał jej prace jako „pierwszorzędne, fundamentalnej wartości”.

Rekonstruuje przebieg habilitacji (pierwszej i jedynej z zakresu teorii literatury, $n b$. też ostatniej habilitacji w dziejach UJK) na podstawie uniwersyteckich dokumentów według Mariusza Chrostka, autora świetnej monografii Złote lata polonistyki lwowskiej (1919-1939), wydanej przez Uniwersytet Rzeszowski w 2016 roku. Zebranie habilitacyjne odbyło się 22 VI 1937. Pierwszy zadawał pytania Kleiner (,stosunek czynników indywidualnych do ponadindywidualnych w stylu literackim”, „uwzględnienie czynników ponadindywidualnych w stylu na terenie ogólnej teorii sztuki i na terenie teorii literatury”, „zagadnienie stylu w teorii renesansu”). Następnie Eugeniusz Kucharski (1880-1952) pytał o „Zadania teorii literatury i jej stosunek do innych dyscyplin literackich”, o „historię literatury wobec krytyki literackiej” oraz o „przyczynowość w historii literatury a przyczynowość w ogóle”. Czerny zaś zaproponował dwie kwestie: „spór o rodzaj literacki w historii literatury XIX wieku” oraz „stanowisko Brunetière'a i Crocego wobec zagadnienia rodzaju literackiego". Uczestniczacy w kolokwium Roman Ingarden (1893-1970) pytał, czy da się uzasadnić - a jeśli tak, to jak - że istnieją rodzaje literackie. Historyk Adam Szelagowski (1873-1961) zapytał zaś o „stosunek teorii literatury do historii”. Następnego dnia Skwarczyńska wygłosiła wykład habilitacyjny Estetyka makaronizmu (opublikowany potem w Pracach ofiarowanych Kazimierzowi Wóycickiemu 〈Wilno 1937〉). Zatwierdzenie tytułu docenta przyszło z Ministerstwa Wyznań Religijnych i Oświecenia Publicznego już 31 VII 1937. A Skwarczyńska do r. 1939, dojeżdżając do Lwowa, prowadziła na uczelni nieregularne wykłady. W tym czasie mieszkała okresowo w Łodzi, gdzie pracowała w Gimnazjum im. Elizy Orzeszkowej oraz w tzw. Pedagogium (egzamin nauczycielski w zakresie polonistyki i romanistyki zdawała jeszcze w 1927 r. przed komisją w UJK). W czerwcu 1939 otrzymała nominację na 
profesora nadzwyczajnego w łódzkim oddziale Wolnej Wszechnicy Polskiej i objęła Katedrę Historii i Teorii Literatury.

Tego wszystkiego $\mathrm{w}$ roku jubileuszu oczywiście nie wiedziałem, a biografię Skwarczyńskiej i bibliografię jej publikacji z okresu tych 40 lat znalazłem, po jakimś czasie, w trzecim tomie Stownika wspótczesnych pisarzy polskich, wydanego przez PWN pod redakcja Ewy Korzeniewskiej i zespołu w r. 1964 (zamieszczone tam hasło było pierwsza publikowaną po drugiej wojnie światowej biografią Pani Profesor i pierwszym wykazem jej dotychczasowego dorobku naukowego). Trzy tomy owego słownika, trudno dostępnego, pożyczałem potem od Pani Profesor podczas kwerend do doktoratu już jako asystent katedry, bo jako pierwsza próba opracowania życiorysów i bibliografii pisarzy i badaczy literatury XX stulecia stanowiły one wtedy jedyne tak rozległe i uporządkowane źródło informacji biograficznych i bibliograficznych, choć ze względów cenzuralnych posługiwano się w nich rozmaitymi eufemizmami bądź przemilczeniami. W przypadku Pani Profesor wygląda ta praktyka np. tak:

Po wybuchu wojny do kwietnia 1940 była docentem na Uniwersytecie im. I. Franki we Lwowie, po czym została przesiedlona do Kazachstanu. W tymże roku powróciła do Lwowa i kontynuowała pracę na Uniwersytecie.

Jak gdyby nigdy nic!

W roku jubileuszowym ukazał się też wtedy specjalny, jej poświęcony tom „Prac Polonistycznych" (seria 20〈1965〉) - Skwarczyńska była ich współzałożycielką w 1937 r. w Łodzi i pierwszym redaktorem - z artykułami m.in. Hermanna Buddensiega, Wiktora Weintrauba, Romana Jakobsona, Marii Jasińskiej, Wandy Lipiec, Marii Janion, Juliusza Kleinera, Zdzisława Stiebera, Henryka Markiewicza, Stanisława Pigonia, Kazimierza Kupisza i Zofii Szmydtowej oraz z dokumentacją bibliograficzną dorobku naukowego jubilatki (pełniejszą niż ta zawarta w Stowniku wspótczesnych pisarzy polskich).

Odbyła się również tłumna uroczystość z dziesiątkami osób (z całej Polski i Łodzi, ze świata nauki, kultury i sztuki), które kwiatami, toastami i życzeniami uczciły uczoną. Uśmiechnięta Pani Profesor w czarnej sukni, z kieliszkiem szampana w ręku, przyjmowała życzenia - wypełniona radością i sympatia - od wszystkich zebranych. Gdy patrzę na zdjęcie $z$ tamtego czasu, dostrzegam też na jej szyi oryginalny naszyjnik ze srebrnych kulek i srebrną bransoletkę $z$ kwiatem na przegubie prawej ręki. Były to indiańskie amulety, które miały przynosić szczęście. To jedyne ozdoby, które Pani Profesor nosiła potem niemal zawsze, ofiarowane jej wraz z innymi pamiątkami przez wnuczkę Heleny Modrzejewskiej, Marylę Modjeską-Pattison (1893-1966) z USA, tuż przed jej tragiczną śmiercią w wypadku samochodowym.

Piszę o wykładzie inauguracyjnym prof. Skwarczyńskiej i o jej jubileuszu, a przecież od pierwszego roku szczególnie pilnie chadzałem na wszystkie zajęcia filmoznawcze, bo sztuce filmowej - jako przyszły, jak myślałem, reżyser - chciałem się poświęcić. I ten temat, wywołany ze studenckiej przeszłości, godny jest oddzielnie pisanej opowieści. Duża grupa, od pierwszego roku studiów, biegaliśmy na zajęcia $z$,wiedzy o filmie” prowadzone przez prof. Bolesława Lewickiego (1908-1981) i jego dwie ówczesne asystentki: mgr Ewę Siemińską i mgr Polę Wert (1925-1987); 
pierwsza przeniosła się wkrótce do Wrocławia, za mężem Januszem Deglerem (potem profesorem, zasłużonym witkacologiem na Uniwersytecie Wrocławskim), i nie kontynuowała pracy uniwersyteckiej (a szkoda - do dziś pamiętam jej świetną rozprawkę z tamtego czasu o „filmowej narracji” Bram raju Jerzego Andrzejewskiego), druga zrobiła doktorat w 1965 r. na temat „widowiska telewizyjnego" (pierwszy w Polsce doktorat o telewizji!), po pamiętnym marcu 1968 otrzymała etat docenta, zresztą $\mathrm{z}$ akceptacją Pani Profesor, bo nowy etat samodzielnego pracownika uznała ona za cenny dla katedry. Dr Pola na tym etacie, w Zakładzie Wiedzy o Filmie i Telewizji, pracowała użytecznie do swojej przedwczesnej śmierci.

Prof. Lewickiego powszechnie wielbiliśmy (wykładał też wtedy - co było dla nas ważne - w łódzkiej szkole filmowej) za talent retoryczny, esprit i, by tak rzec, niezwykłą aktualność (prawie zawsze przychodził na zajęcia z nową książka, która się właśnie ukazała, a która według niego mogła wspierać interpretacje sztuki filmowej i jej humanistyczno-naukowe konteksty). Na owe czasy - co znów trzeba dodać był to pierwszy, jedyny i unikatowy w Polsce, a pewnie i w Europie, uniwersytecki ośrodek wiedzy o filmie! Zatem spotykaliśmy się także w kinach (lata sześćdziesiąte to szczególnie świetny okres w dziejach kina, a i do Polski docierały już wtedy arcydzieła filmu światowego), ale również w dyskusyjnych klubach filmowych, na projekcjach w szkole filmowej i po piracku, na pokazach przedpremierowych dla dziennikarzy w kinie „Stylowy”. Prowadziłem wówczas zapiski o oglądanych filmach: któregoś roku ostatni tytuł filmu zanotowałem - aż trudno dziś uwierzyć - pod numerem 200! Pisywałem też nawet jakieś noty recenzyjne do drukowanych programów kina „Stylowy”.

Tak czy tak, kiedy pojawiły się w ramach studiów polonistycznych w rozkładach zajęć planowane seminaria magisterskie, oczywiście wybrałem to, co poświęcone filmowi. Grupka seminarzystów była dość liczna, $\mathrm{z}$ interesującymi indywidualnościami (z niektórymi z kolegów przyjaźnię się do dziś!), którzy i potem, już po studiach, ciekawie zapisywali się w polskiej i łódzkiej kulturze. Ja - jako beneficjent stypendium naukowego - wpisałem sie jeszcze na dwa seminaria magisterskie: do prof. Anieli Kowalskiej (1905-1997), bo tu obowiąywała bezgraniczna wolność dyskusji i sporów oraz polemiczna wolnoamerykanka (na seminarium dominowała literatura współczesna), oraz właśnie do prof. Stefanii Skwarczyńskiej, bo tu z kolei zapowiadał się poziom wysoce akademicki, powiedziałbym: nobliwy i wielce prestiżowy. Wszystkie te trzy seminaria uważałem wtedy, i uznaję dziś, za kwintesencję ówczesnej swojej edukacji akademickiej.

Pracę dyplomową o polskim filmie poetyckim (m.in. o Ostatnim dniu lata w reżyserii Tadeusza Konwickiego) pisałem jednakowoż pod kierunkiem Lewickiego, a pozostałe dwa seminaria traktowałem jako istotne i ważne dopełnienie moich studiów. Kończyłem je „w terminie”, tj. 22 VI 1966, bo od tego zależały moje plany na przyszłość. Przewodniczył egzaminowi magisterskiemu ów wspomniany profesor od oświecenia (!); nie wymieniam jego nazwiska, bo przemkną przez uczelnię jakby bez historii. Promotorem był oczywiście prof. Lewicki (podobało mu się, że wykorzystałem w pracy magisterskiej głośny tekst Romana Jakobsona Poetyka $w$ świetle językoznawstwa, drukowany wtedy w „Pamiętniku Literackim” w przekładzie Krystyny Pomorskiej), rolę recenzenta pełniła zaś prof. Stefania Skwarczyńska, która również $\mathrm{z}$ aprobatą dostrzegła teoretycznoliterackie konteksty mojej 
filmoznawczej rozprawy. Rozmawialiśmy podczas egzaminu m.in. na temat prądów poetyckich XX wieku, o ekspresjonizmie, surrealizmie i - dłużej - o futuryzmie. Ocena ogólna - bardzo dobra.

Piszę o tym szczegółowiej, bo ów egzamin magisterski zadecydował o mojej dalszej przyszłości. Kilka dni potem otrzymałem bowiem od obojga profesorów propozycję pracy w Katedrze Teorii Literatury (!), jednakże nie asystenturę pod opieką Lewickiego u niego w Zakładzie Wiedzy o Filmie - jak się po trosze spodziewałem - lecz staż asystencki u Pani Profesor w Zakładzie Teorii Literatury. Wprawdzie ze zrozumieniem przyjąłem argumenty obojga profesorów, ale byłem jednak rozczarowany, bo oto musiałem się przekwalifikować z filmoznawcy pewnego swojej wiedzy w przyszłego teoretyka literatury na dorobku. I to w krótkim czasie! Wielce przyjazną opiekę naukową Lewickiego zamienić na nieznane sympatie podopiecznego wielkiej Stefanii Skwarczyńskiej!

Na marginesie dodam: po latach los sprawił, że po śmierci doc. Wertowej, na skutek perturbacji etatowych $\mathrm{z}$ obsadą stanowiska kierownika Zakładu Wiedzy o Filmie i Telewizji w r. 1987, to mnie - równolegle do moich obowiązków literaturoznawczych - powierzono na trzy lata kierownictwo tego zakładu! Prowadziłem więc także filmoznawcze seminarium magisterskie i wypromowałem w tym czasie prawie 40 magistrów. Pracowałem też przez rok jako wykładowca w łódzkiej szkole filmowej, przez dwa lata współredagowałem z Tadeuszem Szczepańskim, dzisiejszym profesorem, „Film na Świecie”, potem jeszcze - już jako docent - recenzowałem filmoznawcze doktoraty! Mówiąc żartem: byłem więc w katedrze nobliwym doktorem Jekyllem od literaturoznawstwa i panem Hyde'em, który wieczorami wymykał się do kina.

$N b$. i Lewicki rozpoczynał, tak jak Skwarczyńska, swoją uniwersytecką edukację w rodzinnym Lwowie. Doktorat, na temat Poeta i Legiony (o twórczości poetyckiej J. Maczki), napisał w r. 1935 na tamtejszej uczelni. Promocja, o czym donosiła „Gazeta Lwowska” (1938, nr 145), odbyła się w r. 1938, a promotorem był także Juliusz Kleiner! Lewicki uczestniczył też wówczas w nieformalnym seminarium filmoznawczym, działającym pod opieką Romana Ingardena, który potem, po r. 1945, pracował na uczelniach w Toruniu i Krakowie.

W tymże seminarium swą wiedzę uzupełniali również: Zofia Lissa (1908-1980), po drugiej wojnie światowej profesor muzykologii oraz teoretyk i estetyk muzyki filmowej, oraz Leopold Blaustein (1905 - po 1942), filozof, estetyk i psycholog. Opublikował Lewicki wtedy trzy rozprawy z zakresu teorii i poetyki filmu, a jego studium Budowa utworu filmowego (1935) było jedna z pierwszych w Polsce istotnych publikacji $z$ teorii filmu - nie licząc książki Karola Irzykowskiego $X$ muza (1924) i ważnego tekstu Juliusza Kleinera U wrót nowej estetyki (1929). W tamtych czasach, aż do r. 1939, był też Lewicki nadzwyczaj płodnym i aktywnym recenzentem filmowym i teatralnym, pisał setki tekstów i omówień do lwowskiej prasy codziennej. Wybuch wojny zastał go w Toruniu, gdzie pracował w Polskim Radiu jako szef programowy. Opuszczał to miasto w pośpiechu, poszukiwany przez hitlerowców.

Działalność dydaktyczną tuż po wojnie Lewicki rozpoczynał w łódzkiej Wyższej Szkole Filmowej (założonej w r. 1947), która powstała na gruncie wcześniejszych inicjatyw dydaktycznych tego rodzaju - z krakowskiego Warsztatu Filmowego Młodych Antoniego Bohdziewicza (założonego w r. 1945) oraz z Wydziału Filmowego 
w łódzkiej Wyższej Szkole Sztuk Plastycznych (w 1946) i Kursu Przysposobienia Filmowego (1946), przekształconych następnie w Wyższe Studium Filmowe (1948), a których pomysłodawcą i współtwórcą był m.in. dyrektor Marian Wimmer (18971970), absolwent architektury na Politechnice Lwowskiej i filmowiec amator, m.in. autor filmu o Karolu Szymanowskim. Lewicki pracował tam (od 1958 r. równolegle z etatem w UŁ) przez długie lata, także w czasie przemian organizacyjnych szkoły i zmian jej nazwy w Państwową Wyższą Szkołę Teatralną i Filmową. W latach 1968-1971 pełnił nawet funkcję jej rektora, po prof. Jerzym Toeplitzu (1909-1995), znakomitym historyku kina światowego, poprzednio dyrektorze szkoły (od 1949), a następnie jej rektorze (od 1958).

Stefanię Skwarczyńską, wykładowczynię Wyższej Szkoły Aktorskiej, powstałej wtedy równolegle $z$ Wyższą Szkołą Filmową (i tu Pani Profesor prowadziła zajęcia) w Łodzi w r. 1949, Lewicki mógł poznać u początków swojej pracy w Łodzi - jeśli nie znał jej (co więcej niż prawdopodobne) już w czasach lwowskich. Spotkał tu też wybitnego reżysera teatralnego Leona Schillera (1887-1954), którego również znał blisko ze Lwowa. (W okresie wojny los zetknął ich obu jeszcze w $1941 \mathrm{r}$. w obozie koncentracyjnym Auschwitz-Birkenau. Schiller, a spośród aktorów także Stefan Jaracz zostali po kilku miesiącach zwolnieni $\mathrm{z}$ obozu.)

Po latach Kazimierz Kutz (1929-2018), student i absolwent łódzkiej filmówki, wspominał w swojej biografii:

największe wrażenie robiła na mnie profesor Stefania Skwarczyńska. Przede wszystkim używała języka polskiego jak nikt przed nią. Po raz pierwszy usłyszałem piękno mowy polskiej, słuchając jej wykładów, doznałem estetycznego wstrząsu, jak przy zetknięciu ze sztuką, choć były to precyzyjne wywody naukowe o strukturze wewnętrznej arcydzieł literatury dramatycznej [...]. Co to jest ekspozycja, a co finał, i co się na nie musi złożyć, co to jest motyw przewodni i rola wątku ubocznego, i tak dalej. Precyzyjna logika wywodów Pani Stefanii przylegała do odsłanianych tajemnic dzieła, a dzięki bogactwu i krasie jej polszczyzny, niezwykłej obrazowości, jej wykłady przeobrażały się w seanse estetyczne. Wciagała nas w dyskusje, mogliśmy stawiać pytania i jej odpowiedzi zawsze były nadspodziewane.

Obie placówki dydaktyczne, teatralną i filmową, przekształcono w r. 1958 w jedną i nadano jej imię dopiero co zmarłego Schillera. Ten wybitny artysta teatru wprawdzie lwowianinem $z$ urodzenia nie był, ale w okresie międzywojennym reżyserował w tamtejszych teatrach wielkie dzieła polskich romantyków i dramaty innych autorów. A Skwarczyńska, która te inscenizacje mogła oglądać właśnie we Lwowie, opublikowała w r. 1959 swoje monumentalne dzieło teatrologiczne, zatytułowane Leona Schillera trzy opracowania teatralne „Nie-Boskiej komedii” $w$ dziejach jej inscenizacji $w$ Polsce, w którym interpretowała analitycznie Schillerowskie dzieła teatralne.

Jednym z recenzentów lwowskiej inscenizacji Nie-Boskiej komedii z r. 1935 w reżyserii Wacława Radulskiego w „Gazecie Lwowskiej” był też jej stały współpracownik i krytyk, czyli Lewicki właśnie, podpisujący się trzema literami: b.w.l. Tak właśnie na studiach nazywaliśmy czule Profesora - „Be-wu-el”, choć nie wiedzieliśmy nic o jego dziennikarskiej i radiowej przeszłości ani o tym, że systematycznie publikował recenzje teatralne i filmowe oraz inne teksty np. w lewicowych „Sygnałach” (1933-1939), w „Gazecie Lwowskiej” (1810-1939) i w „Słowie Polskim” (1895-1946). Lewicki nadzwyczaj aktywnie uczestniczył też we lwowskim życiu literackim i kulturalnym. Jeden ze sporów publicystycznych, co ciekawe, finalizo- 
wał nawet w pojedynku na szable (zwycięskim - dodam - do pierwszej krwi) z niejakim Tadeuszem Ulanowskim, endeckim dziennikarzem, którego lekko ranił w policzek w lutym 1932. Niestety, nie dotarłem do szczegółów i przyczyny tego pojedynku.

Lewicki współtworzył jako członek założyciel Klub Filmowy „Awangarda”, który w latach 1932-1936 upowszechniał we Lwowie kulturę filmową i wydawał periodyk o takim tytule, redagowany przez Tadeusza Hollendra (1910-1943), maturzystę ze Stanisławowa, poetę, publicystę oraz studenta prawa i polonistyki Uniwersytetu Jana Kazimierza. Upamiętniając poetę, Skwarczyńska wraz z Lewickim w r. 1963 opublikowali w Wydawnictwie Literackim, we wspólnym opracowaniu, pokaźny tom Hollendra Liryka i satyra. We wstępnym „szkicu o życiu i twórczości” zamieszcza Skwarczyńska jedno znamienne zdanie charakteryzujące jego tamtejszą sytuację egzystencjalną: „Jako wszystkim znany obrońca Żydów i radykał był Hollender za czasów okupacji hitlerowskiej szczególnie zagrożony we Lwowie. Toteż w r. 1941 przenosi się do Warszawy". Tam poeta wkrótce został aresztowany i rozstrzelany przez hitlerowców w ruinach getta warszawskiego 31 V 1943. Pani Profesor - dodam - jest także autorką hasła poświęconego Hollendrowi w Polskim słowniku biograficznym (t. 9, z. 40).

Na marginesie lwowskich faktów trzeba dopisać: prof. Jerzy Starnawski (19222012), filolog i historyk literatury (łodzianin $z$ zamieszkania, absolwent KUL-u i wykładowca w UŁ), m.in. niestrudzony kronikarz literaturoznawstwa polskiego, poświęcił profesorom lwowskim o takiej specjalności wcale obszerną książkę, w której omawia 22 biografie wykładowców Uniwersytetu Jana Kazimierza w kontekstach dziejów tej wybitnej uczelni do 1939 roku.

Na łódzkiej uczelni (pomijam tu inne) pracowali przez jakiś czas jeszcze inni oprócz Skwarczyńskiej i Lewickiego - profesorowie urodzeni we Lwowie: filozof Tadeusz Kotarbiński, teoretyk literatury Jan Trzynadlowski (profesurę uzyskał już we Wrocławiu), historyk literatury Stefan Kawyn, filozof Jan Legowicz, językoznawcy Henryk Ułaszyn, Karol Dejna i Zdzisław Stieber, bibliotekoznawcy Adam Łysakowski i Helena Więckowska, polonista i psycholog Stanisław Gerstmann (promotor psychologicznego magisterium mojej żony Ireny) oraz Lidia Łopatyńska (19091954; romanistka, absolwentka UJK, bliska współpracowniczka Pani Profesor $\mathrm{w}$ wielu literaturoznawczych przedsięwzięciach).

Wracając do swojej biografii uniwersyteckiej: dzisiaj, po prawie 50 latach pracy w Uniwersytecie Łódzkim i na emeryturze, trudno mi te początkowe rozczarowania, o jakich wspomniałem, roztrząsać, ale mogę powiedzieć, że wtedy całkiem tego nie świadom, dziś tamto rozstrzygnięcie zawodowe uznaję za nieprzewidziany dar losu. Tak oto po studiach stałem się niespodziewanie asystentem stażysta prof. Stefanii Skwarczyńskiej (to zdanie koniecznie muszę zamknąć wykrzyknikiem)! I zaraz, od października tego samego roku, przewidziano dla mnie cztery grupy ćwiczeniowe z poetyki, stylistyki i wersyfikacji na drugim roku polonistyki. O filmie jednak nie zapomniałem i wciąż mogłem liczyć na sympatię prof. Lewickiego: zawsze znajdował chwile na rozmowy ze mną, bywałem zapraszany na zwyczajowe pogawędki do kawiarni przy Grand Hotelu na Piotrkowskiej, potem także do jego domu. Pożyczaliśmy sobie do przeczytania nowo zdobyte książki.

Poznałem jego dramatyczne losy wojenne (przez ponad pół dekady więzień 
6 niemieckich obozów koncentracyjnych - Wiśnicza, Auschwitz-Birkenau, Gross-Rosen i Dachau, Flossenburga i Pottenstein) dopiero wtedy, gdy opublikował był swoje wspomnienia w książce Wiesz, jak jest, sygnowanej przez Wydawnictwo Łódzkie w 1974 r. (reedycja przez PWSFTviT w 2012). Przechowuję ją też ze względu na autorską dedykację: „Z zapewnieniem przyjaźni” ( $n b$. w książce Bolesława Olszewicza Straty kultury polskiej z 1947 r. można było znaleźć znamienną dla tamtych czasów notatkę: „Lewicki Bolesław Włodzimierz - publicysta, filmolog zginął w obozie w Oświęcimiu").

W październiku 2019 w łódzkiej alei wybitnych postaci polskiego filmu na ul. Piotrkowskiej odsłonięto - przy licznym zgromadzeniu jego uczniów, seminarzystów i kontynuatorów idei filmoznawstwa - kolejna gwiazdę: $\mathrm{z}$ nazwiskiem prof. Bolesława Lewickiego właśnie. Obecny był tam m.in. jego najbardziej aktywny naukowo uczeń, teraz z tytułem profesora zwyczajnego, Tadeusz Szczepański, który jako student z Uniwersytetu im. Adama Mickiewicza pielgrzymował i przenosił się do Łodzi, do naszego Zakładu Wiedzy o Filmie, pod naukowe skrzydła Lewickiego, aby w następnych dziesięcioleciach rozwijać studia filmoznawcze na uniwersytetach Gdańska (tu jeszcze wraz z Profesorem), Torunia i Wrocławia oraz w łódzkiej filmówce. Na marginesie (to apel!): uczniowie Profesora oraz inni adepci teorii i historii filmu mogliby pokusić się o napisanie dużej biografii Lewickiego jako ważnego animatora filmoznawstwa akademickiego oraz badań nad kulturą filmową w Polsce (jakieś pisane próby podejmowano w przeszłości). Ja np. już nie miałbym dziś sił, aby podróżować do Lwowa i jego archiwów. Choć przygotowując się do tego tekstu, niedawno chadzałem jako turysta po wiosennych ulicach Lwowa - poszukiwałem jego przedwojennych nastrojów i chłonąłem je.

Pomieszczenia Katedry Teorii Literatury, czyli miejsca mojej pierwszej po studiach pracy, znajdowały się na drugim piętrze w bocznym skrzydle biblioteki uniwersyteckiej. Były to trzy obszerne sale, $z$ wysoko umieszczonymi oknami, przedzielone sięgającymi sufitu regałami, którymi zresztą obstawione były też niemal wszystkie ściany. Salę największą, na prawo od wejścia, zajmował katedralny Zakład Teorii Literatury, $\mathrm{z}$ dużym, usytuowanym $\mathrm{w}$ głębi, solidnym biurkiem $\mathrm{z}$ lampą i czarnym telefonem oraz wygodnym fotelem $z$ półokragłym oparciem. I była to wyłączna domena Pani Profesor. Biurka pracowników zakładu ustawiono zaś pod ścianami, które we wmontowanych regałach zapełnione były od góry do dołu książkami katedralnej biblioteki. Pośrodku sali stał niski kwadratowy stolik z czarnym szklanym blatem, otoczony kilkoma fotelami w lotniczych barwach. To było miejsce na prywatne rozmowy przy kawie, papierosach i herbacie. $\mathrm{W}$ tamtych latach palili niemal wszyscy (Pani Profesor, a także Lewicki wkrótce rzucili palenie), a podczas zebrań zespołu chmura dymu unosiła się aż po wysoki sufit, co poświadczają zdjęcia $z$ tamtych lat.

$Z$ lewej strony od drzwi usytuowany był Zakład Wiedzy o Filmie o podobnym rozkładzie i układzie biurek (największe służyło oczywiście kierownikowi zakładu, czyli Bolesławowi W. Lewickiemu, wówczas jeszcze docentowi). Tam znajdował się też solidny stół do pracy dla gromadzących się przy nim grupek magistrantów lub doktorantów, albo „zwyczajnych” fanów z „miasta”. Nierzadko pośród licznych uczestników gościła na tych seminariach, jako wolny słuchacz, Maria Kornatowska (1935-2011), wykładowczyni szkoły filmowej i podziwiana bywalczyni zagranicznych 
festiwali filmowych, autorka (m.in.) znakomitej ksiażki o twórczości Federica Felliniego (cztery wydania!). I tu ściany obstawione były regałami z dziesiątkami książek - oczywiście filmoznawczych, polskich i obcych - na ów czas nie tak znowu licznych.

$\mathrm{W}$ pomieszczeniu środkowym, naprzeciw drzwi, kiedy zaczynałem prace w katedrze, stało duże biurko adiunkta dr. Kazimierza Kupisza (1921-2003), jedynego pracownika Katedry Filologii Romańskiej UŁ, która organizacyjnie zawieszona, bo jednoosobowa, czekała na lepsze czasy pod opieką kuratorską prof. Skwarczyńskiej. I to pomieszczenie okalały regały z książkami, tym razem francuskojęzycznymi, które skrzętnie gromadził i opracowywał kwaśno uśmiechający się na ogół pan doktor (chyba jednak trochę się lubiliśmy? - podczas studiów chadzałem na jego wykłady $z$ historii literatury francuskiej). $N b$. po paru latach Kupisz habilitował sie (1968) i uzyskał profesurę (1984); uczelnia utworzyła potem regularne studia romanistyczne, a on, ich szef, wraz z całym swoim bibliotecznym gospodarstwem, wyprowadził się, ku zadowoleniu swojemu i nas wszystkich. Później, jak się okazało, nawet zaczął pisać wiersze (ale po polsku); pośredniczyłem, na jego prośbę, w rozmowach $z$ wydawcami, bodaj nieskutecznie.

Sąsiedztwo romanistyki przy Katedrze Teorii Literatury wcale nie było przypadkowe. Stefania Skwarczyńska przez kilka lat - jak napisałem - pełniła funkcję jej kuratora $\mathrm{i}$ to ona $\mathrm{w}$ istocie doprowadziła do powstania najpierw Zakładu, a potem Katedry Filologii Romańskiej na UŁ oraz następnie do uruchomienia regularnych studiów romanistycznych. Sama zresztą miewała zajęcia $z$ tego zakresu już jako docent na uniwersytecie we Lwowie, a także po wojnie w Łodzi, w czasach, kiedy na UŁ zamknięto jej katedrę. Znała język doskonale, pisywała i publikowała po francusku teksty naukowe.

Na miejscu po placówce dr. Kupisza biurka mogli ustawić nasi pracownicy, nowo powołanego w katedrze Zakładu Dramatu i Teatru (1969) pod kierownictwem doc. dr. hab. Stanisława Kaszyńskiego (1927-1988), pracującego na łódzkiej uczelni od r. 1950, a od 1958 już w Katedrze Teorii Literatury, nb. późniejszego profesora (1974) i dyrektora Instytutu Teorii Literatury, Teatru i Filmu (1978-1981; byłem w tamtym czasie jego formalnym zastępca). Zakład powstał w 1975 r. na gruncie teatrologicznych osiagnięć katedry, jeszcze przed przejściem na emeryturę (pod koniec pracy w UŁ) jego pomysłodawczyni, Stefanii Skwarczyńskiej, m.in. promotorki tzw. teatralnej teorii dramatu, dyskutowanej w swoim czasie bardzo aktywnie.

W sprawie opóźniającej się ponad miarę formalnej akceptacji wniosku o tytuł profesora dla Kaszyńskiego szefowa postanowiła napisać list z grzeczną interwencją do Zenona Kliszki, który wówczas podobno, jako członek Biura Politycznego KC PZPR, zajmował się sprawami nauki. I rzeczywiście, w niedługim czasie Kaszyński uzyskał tak oczekiwany tytuł (1974). Pytałem wtedy Pani Profesor, czy Kliszko odpowiedział na jej list, i usłyszałem: „Panie Grzesiu, a czy Pan Bóg - odpowiada na nasze modlitwy?"

W czasie mojego pracowniczego debiutu w r. 1966 zespół katedry, oprócz dwójki szefów, tj. Bolesława Lewickiego i Stefanii Skwarczyńskiej, tworzyli teoretycy literatury - dr Teresa Cieślikowska (ur. 1926 we Lwowie 〈co podkreślam!), w katedrze od r. 1958, doktorat o powieściach Teodora Parnickiego 〈nb. w młodości badacza 
twórczości Słowackiego pod kierunkiem Kleinera na lwowskim uniwersytecie!), habilitacja na temat „nowej powieści”, profesura zwyczajna w r. 1991 i stanowisko dyrektora instytutu w latach 1981-1997); dalej - dr Jerzy Rozental (1930-1998; doktorat o dramaturgii Stanisława Wyspiańskiego; w katedrze od r. 1958; erudyta i znawca języków, życzliwie i wyrozumiale wspomagał nas, młodych, w poruszaniu się po meandrach literaturoznawstwa); następnie - magister przed nieodległym doktoratem - Henryk Pustkowski (ur. 1938), świetny znawca twórczości Mirona Białoszewskiego i współczesnej poezji; dalej - starszy ode mnie o rok mgr Sławomir Świontek (1942-2001; kierował Katedrą Dramatu i Teatru w latach 1994-2001), teoretyk i historyk teatru, oraz też wówczas nowo przyjęty, jak ja, ale starszy o kilka lat, literaturoznawca mgr Andrzej Starzycki, wkrótce z doktoratem u Skwarczyńskiej, a także filmoznawca, kolega $z$ roku, Janusz Rek (ur. 1943), który dołączył do wspomnianej, będącej już po doktoracie (1965) Poli Wert. Sam po latach zrobił doktorat $\mathrm{u}$ Lewickiego na temat motywów samotności w filmie (dobra recenzja Żółkiewskiego), a potem napisał i wydał monografię o twórczości Jerzego Kawalerowicza.

W następnym roku etat asystencki, w przyszłej katedralnej placówce teatrologii, otrzymała mgr Urszula Aszyk (ur. 1944; doktorat u Kaszyńskiego i książka o teatrze Iwo Galla), która po latach pracy lektorskiej w Madrycie, jako autorka licznych studiów i książek, wybitna hispanistka, otrzymała etat profesora zwyczajnego Uniwersytetu Warszawskiego. Wykłada obecnie zarówno u siebie w Instytucie Studiów Iberyjskich i Iberoamerykańskich, którym kieruje, jak i na wielu zagranicznych uczelniach.

$Z$ biegiem lat katedra/instytut się rozrastały, znacząco po powołaniu samodzielnych studiów kulturoznawczych, kiedy zespół pracowników liczył już kilkadziesiąt osób. Wielu z nich, zwłaszcza wychowankom, pisząc historię placówki (ten tekst nią nie jest), należałoby poświęcić oddzielne miejsce, np. późniejszym profesorom tytularnym - historyczce teatru Annie Kuligowskiej, teatrolożce Małgorzacie Leyko, teoretykowi mediów Ryszardowi Kluszczyńskiemu, teoretykowi literatury Jarosławowi Płuciennikowi, specjalistce od edukacji filmowej Ewelinie Nurczyńskiej-Fidelskiej (1938-2016; doktorat w Katowicach, u prof. Alicji Helman, i habilitacja we Wrocławiu), i literaturoznawcom $z$ etatami profesorów nadzwyczajnych - Danucie Szajnert oraz moim doktorom, teraz też już profesorom nadzwyczajnym, po habilitacjach, Agnieszce Izdebskiej (obecnie kieruje Katedra Teorii Literatury, autorka monografii pisarstwa Władysława Lecha Terleckiego) i Mariuszowi Gołębiowi (znawca Białoszewskiego i poetyki ogrodów) oraz Leszkowi Engelkingowi (znany poeta i tłumacz, autor książek o czeskiej awangardzie i Vladimirze Nabokovie), Agnieszce Gawron (monografia o powieściach Andrzejewskiego) i Beacie Śniecikowskiej (obecnie profesor nadzwyczajny w IBL PAN, znawczyni polskiego futuryzmu i monografistka haiku). I po równie swietnych doktoratach - Agnieszce Przybyszewskiej (książka o tzw. liberaturze), Joannie Podolskiej (doktorat o Andrzeju Bobkowskim) i Annie Ciarkowskiej (doktorat o Annie Langfus i Piotrze Rawiczu) oraz także Natalii Lemann $z$ napisaną właśnie książką-habilitacją na temat fabuł alternatywnych w literaturze. $Z$ instytutu wyrósł - by tak powiedzieć - inny mój doktor, adiunkt Maciej Świerkocki, autor książki o postmodernizmie, a teraz - już na wyłącznie własny rachunek - znakomity tłumacz literatury anglojęzycznej (m.in. Joseph Con- 
rad i James Joyce). Oraz - inny mój doktorant - profesor nadzwyczajny Konrad Tatarowski, który najpierw zamierzył doktorat o Zbigniewie Herbercie (poeta wspomina go kąśliwie w jednym ze swoich autobiograficznych komentarzy), aby napisać ostatecznie dwie książki o pisarzach i literaturze „obecnej” na falach Radia „Wolna Europa” (jako działacz internowany w r. 1981, potem dłużej przebywał w USA i w Niemczech; tam pracował we wspomnianym radiu; po powrocie do kraju, ponownie zatrudniony w Uniwersytecie Łódzkim, podjął studia doktoranckie pod moim kierunkiem). Powołano go też ostatnio do rady programowej łódzkiej rozgłośni. A trzeba by wymienić jeszcze nazwisko Bogdana Banasiaka, naszego katedralnego wychowanka, dziś już samodzielnego pracownika, doktora filozofii, wypromowanego przez prof. Stefana Morawskiego, tłumacza tekstów markiza de Sade’a, interpretatora i wydawcy Jacques'a Derridy (we własnych przekładach).

Nie wspominam o filmoznawcach, którzy na tyle wybili się $\mathrm{w}$ instytucie na naukowo-badawczą samodzielność, że prowadzą obecnie w jego ramach niezależny kierunek studiów filmoznawczych (ich szef, prof. nadzw. Marek Sitarski, jest teraz dyrektorem całego Instytutu Kultury Współczesnej).

Kontynuujemy więc - my, reprezentanci kilku pokoleń literaturoznawców, teatrologów i filmoznawców - dzieło Skwarczyńskiej i Lewickiego, ów trójnawowy „model łódzki”, na miarę wyzwań współczesności, jakiej w swoich czasach nasi mistrzowie nawet nie mogli przewidywać. A przecież byli jeszcze i stażyści, wykładowcy i profesorowie z zaprzyjaźnionych uczelni polskich (m.in. Alicja Helman, Chone Shmeruk, Dobrochna Ratajczakowa, Tadeusz Lubelski, Krzysztof Loska, Andrzej Werner, Wiesław Godzic, Zbigniew Czeczot-Gawrak, Józef Robakowski, Grzegorz Królikiewicz, Paweł Edelman), którzy gościnnie prowadzili zajęcia bądź wykłady i seminaria magisterskie, wzbogacające naszą ofertę edukacyjną.

W katedrze/instytucie gromadzili się także podczas seminariów magistranci i doktoranci oraz inni słuchacze, którzy po uzyskaniu u nas, w Łodzi, doktoratów zatrudniani bywali potem $\mathrm{w}$ wielu polskich uczelniach (tam $\mathrm{z}$ naukowymi osiagnięciami!) i którymi nie sposób się tu zajmować (wiele, wiele nazwisk!). Sama prof. Skwarczyńska wypromowała 25 doktorów, była recenzentką w dziesiątkach doktoratów, habilitacji i profesur w uczelniach całej Polski, prof. Cieślikowska wypromowała 17 doktorów oraz ja tyleż samo, a i pozostałe doktoraty - innych samodzielnych pracowników katedry - należałoby w sumie liczyć w dziesiątkach. Dzisiaj bardzo wielu $z$ nich, już jako profesorowie i samodzielni badacze, pracuje na polskich uczelniach.

Wróćmy jednakowoż do mojej chronologii. Podczas stażu udało mi się jeszcze w ciagu roku akademickiego wyjechać na fundowany przez Zrzeszenie Studentów Polskich dwutygodniowy pobyt w Czechosłowacji. Nie wiedziałem, jak uzyskać zgodę Pani Profesor, bo przecież dopiero co podjąłem staż! Wymyśliłem więc konsultacje z praskim profesorem Zdeňkiem Mathauserem (1920-2007), rusycystą, autorem monografii o Włodzimierzu Majakowskim i studiów na temat futuryzmu rosyjskiego.

Uzyskawszy domowy adres profesora, zapowiedziałem się z wizytą. I rzeczywiście do spotkania doszło. Konsultacja była bardzo życzliwa, otrzymałem też - z dedykacją - książkę o rosyjskim futuryście. Miałem więc o czym opowiedzieć po powrocie do Łodzi. Od tamtego czasu zostałem w oczach Pani Profesor - na wyrost - 
„panem Grzesiem, naszym bohemistą, wpisanym też z językiem czeskim (wtedy na wyrost!) na listę Poradni Językowej dla studentów.

Ale potem istotnie przez lata całe bywałem u Czechów i Słowaków (w Nitrze, w Bratysławie, Bańskiej Bystrzycy, w Brnie i Pradze) na wspólnych konferencjach, publikowałem tam rozmaite artykuły i nawiązałem serdeczne przyjaźnie. Literaturoznawcy z Pragi i Bratysławy bywali i publikowali z kolei u nas w Łodzi. Nauczyłem się - aby móc czytać - czeszczyzny. Pokochałem Pragę i prozę Bohumila Hrabala. A w swoich słownikach zawsze starałem się należycie uwzględniać tradycje XX-wiecznej literatury zza naszej południowej granicy, czeskiej i słowackiej. Swego czasu powstał nawet projekt przekładu jednego z nich (Słownik europejskich kierunków i grup literackich $X X$ wieku) na język czeski i może by tak się stało, gdyby nie przedwczesna śmierć tamtejszego polonisty z Brna, prof. Ludvíka Štěpána (1943-2009), który zabierał się poważnie do tłumaczenia (wydał m.in. Slovník polských spisovatelů 〈Praha 2000〉). A dzisiaj, w grudniu 2019, ambasador Republiki Czeskiej otworzył na Wydziale Filologicznym UŁ studia bohemistyczne!

Jeśli już o słownikach mowa, to w Belgradzie, w tłumaczeniu na język serbski, ukazał się pod moją i Słowini Tyneckiej redakcją Słownik rodzajów i gatunków literackich (pierwsze wydanie, opracowane przez zespól Katedry Teorii Literatury), z czego zapewne cieszyłaby się bardzo Pani Profesor, projektodawczyni tego słownika i jego redaktor w czasach, kiedy poszczególne hasła były publikowane w „Zagadnieniach Rodzajów Literackich” od 1958 roku. Drugie, potężne wydanie słownika, istotnie poszerzone i uzupełnione, ukazało się w 2012 r. w PWN-ie. A dopiero co dowiedziałem się $z$ wydawnictwa o znacznym dodruku tej grubej księgi.

Tak więc wielki projekt Pani Profesor, ogłaszany już na przełomie lat czterdziestych i pięćdziesiątych XX stulecia, stał się ciałem. Zarys tego przedsięwzięcia - co trzeba przypomnieć - powstał tuż po wojnie w ramach zamierzeń badawczych Łódzkiego Towarzystwa Naukowego (literaturoznawcy rozmawiali też na ten temat jeszcze na tajnych posiedzeniach Lwowskiego Towarzystwa Naukowego w czasie niemieckiej okupacji!). Następnie, w r. 1947, na zebraniu Łódzkiego Towarzystwa Naukowego Pani Profesor ogłosiła Projekt „Stownika rodzajów literackich” i opublikowała go w „Sprawozdaniach z Czynności Posiedzeń ŁTN” (także po francusku). Powstała więc specjalna komisja, która udała się do Warszawy, do utworzonego niedawno Instytutu Badań Literackich. W ustalonym terminie na posiedzenie w Pałacu Staszica stawili się łodzianie z Panią Profesor na czele (m.in. pojawił się też Juliusz Kleiner jako profesor Uniwersytetu Jagiellońskiego!). Ze strony instytutu mieli w spotkaniu wziąc udział Stefan Żółkiewski, Maria Renata Mayenowa, Kazimierz Budzyk i Jan Kott. W ciagu godziny - opowiadała potem Pani Profesor nikt z gospodarzy się nie pokazał. Wpadł tylko na chwilę Kott, aby „Z właściwym sobie wdziękiem pogadać o ewenementach w ówczesnym światku literackim". Żółkiewski o tym, że nie ma czasu, zawiadomił gości przez woźnego.

Poza dydaktyką na pierwszych latach polonistyki do moich obowiązków w katedrze, jako najmłodszego pracownika, należało sekretarzowanie Pani Profesor przy telefonie, maszynie do pisania, przy innych powinnościach administracyjnych, częściowa opieka nad księgozbiorem, także wszelka inna pomoc - bo trzeba pamiętać, że Szefowa po niegdysiejszym wypadku nie radziła sobie bez laski. Profesor odbywała swoje uniwersyteckie powinności na ogół we wtorki i w czwartki, zatem 
w te dni można było się spodziewać rozmaitych dodatkowych obowiązów. Mimo że mieszkała przy ul. Narutowicza 67, czyli kilkaset metrów od biblioteki uniwersyteckiej, w dni jej pracy i konsultacji przywoziliśmy i odwoziliśmy ją zamawianymi taksówkami.

Dużo czasu spędzałem wtedy przy maszynie do pisania, można nawet powiedzieć, że wówczas na dobre nauczyłem się nią posługiwać, choć już pracę magisterską wystukałem sobie sam. W katedrze nie było odpowiedniego sekretariatu ani żadnej sekretarki, a biurokracja, nawet w najlepszym tego słowa pojęciu, była obfita i uciążliwa. Jako najmłodszy stażysta siadywałem więc przy maszynie niby sekretarka, obok Pani Profesor z papierami, i mnożyliśmy wówczas rozmaite pisma, listy i sprawozdania, niekiedy dosyć męczące. Pani Profesor - co oczywiste - swój korespondencyjny savoir-vivre kształtowała przed wojną, a przy tym bywała dość drobiazgowa, co niejednokrotnie kłóciło się $z$ moimi biurowymi doświadczeniami (przez kilka lat byłem - jako działacz Zrzeszenia Studentów Polskich w latach sześćdziesiątych - kierownikiem Komisji Kultury, a nawet wiceprzewodniczącym w Radzie Uczelnianej UŁ, tam też kwitła socjalistyczno-biurokratyczna wymiana papierów, zatem w tych sprawach kształtowałem także swój osobisty punkt widzenia). Często więc musiało dochodzić do różnicy zdań. Gdy miałem wątpliwości co do nazbyt wykwintnej frazeologii, niekiedy - mówiąc krótko - niedzisiejszej, na różne sposoby odczytywałem proponowane frazy, aby i Pani Profesor zwróciła uwagę na swoje stylistyczne projekty. Mówiąc żartem - miałem jakiś wpływ na urzędową stylistykę katedry! A bywały okresy nasilonych sprawozdań, planów, zamierzeń i próśb na temat propozycji personalnych na przyszłość oraz projektów naukowych, planowanej liczby książek i artykułów, ale i materiałów biurowych, herbaty itp.

Nierzadko były to nader optymistyczne manifesty związane $z$ rozwojem katedry, ilością przyszłych doktoratów, docentur i profesur oraz innych futurologicznych faktów, które w oczach peerelowskich władz ministerialnych miały potwierdzać ciagły rozwój nauki, instytucji i wzrost liczby uczonych. Nie znaczy to, że zmyślaliśmy, ale raczej to, że Pani Profesor o przyszłości swojego zespołu i placówki, którą kierowała, myślała zawsze nader optymistycznie. Tu, uprzedzając chronologię o dziesiątki lat, mogę dodać, że ta korespondencyjna freblówka z Panią Profesor wspomagała mnie logistycznie potem, gdy sam po latach przez dekade prowadziłem katedrę i instytut, jako ich kierownik i na koniec dyrektor (w latach 1997-2015) z administracyjną i logistyczną pomocą adiunkta-literaturoznawcy, niezastąpionej dr Ireny Hübner, która wspierała mnie w obowiązkach zastępcy dyrektora.

Po roku pracy - wracam do chronologii - okazało się, że ów mój staż na pstrym koniu jeździł. Bo oto katedra od nowego roku akademickiego nie dostała etatu asystenckiego, który miał być przeznaczony właśnie dla mnie, mimo planów dydaktycznych w sprawozdaniach, które sam pilnie na maszynie wystukiwałem! Pani Profesor, nie otrzymawszy zapewnienia o tym etacie w Uniwersytecie Łódzkim, złożyła wizytę w Warszawie ówczesnemu dyrektorowi Instytutu Badań Literackich, prof. Kazimierzowi Wyce (1910-1975), aby zorientować się w możliwościach przyjęcia mnie do Studium Doktoranckiego, które właśnie tam otwarto. I dopiero wtedy poinformowała mnie o wszystkich okolicznościach dalszego zatrudnienia: oto będę doktorantem IBL-u w Warszawie, ze stypendium równym pensji asystenta, Pani Profesor będzie moim promotorem, a praktyki dydaktyczne będę mógł odbywać 
w łódzkiej Katedrze Teorii Literatury. Czy można byłoby znaleźć lepsze rozwiązanie?! Pytanie retoryczne.

Po dwóch latach comiesięcznych wypraw do warszawskiego Pałacu Staszica (tam do dziś ma swoją siedzibę IBL PAN), ale też bytności i dyżurów w łódzkiej katedrze, kiedy mogłem solidniej pracować nad doktoratem, władze UŁ przyznały mi etat starszego asystenta. Wróciłem zatem wkrótce w sposób pełnoprawny na rodzime łono, kontynuując jednak regularne podróże na seminaria iblowskie, świetnie prowadzone przez dwójkę młodych docentów, Alinę Brodzką (1929-2011) i Michała Głowińskiego (ur. 1934). Był to dla mnie w mojej literaturoznawczej edukacji okres bardzo ważny; nauka o literaturze przeżywała doniosły dla jej XX-wiecznych dziejów zwrot strukturalistyczny, którego „centrala” w Polsce był Instytut Badań Literackich i jego dwaj czołowi badacze - właśnie Michał Głowiński i Janusz Sławiński (1934-2014), nb. obaj wtedy po świeżych habilitacjach na podstawie ważnych książek. Nie kłóciło się to z postawami naukowymi Stefanii Skwarczyńskiej, która na łódzkim seminarium doktoranckim (bywałem na nich obowiązkowo) też przybliżała nam m.in. książkę Essais critiques $(1964,1972)$ francuskiego papieża strukturalizmu, Rolanda Barthes'a, cytując obszerne fragmenty ze swoimi komentarzami. Dla mnie, dla Sławka Świontka i innych starszych kolegów $z$ katedry były to spotkania wielce pouczające (Sławek, po doktoracie u Kaszyńskiego, o dramatach Norwida, rozjaśniał metodologię strukturalistyczną w oddzielnych studiach i pozostawał jej konsekwentnie wierny także w następnych tekstach, np. w swojej znakomitej rozprawie habilitacyjnej Dramat, dialog, metateatr 〈dwa wydania〉, której byłem recenzentem; warto też wspomnieć o jego przekładzie z języka francuskiego znanego dzieła - wraz z ważkimi własnymi uzupełnieniami merytorycznymi i bibliograficznymi - czyli Patrice'a Pavisa Stownika terminów teatralnych, opublikowanego w 1998 r. przez wrocławskie Ossolineum). Sławek uzyskał w instytucie etat profesora nadzwyczajnego i kierował Zakładem Dramatu i Teatru.

Tak więc miałem w owym czasie dwie znakomite okazje edukacyjne - łódzką i warszawską. Uczestnictwo w spotkaniach warszawskich dawało mi niezwyczajną perspektywę na badania literackie w Polsce i poza jej granicami. W Łodzi doc. Kaszyński ochrzcił mnie zaraz, na powstałą okoliczność, ,iblowską wtyczką”. A w tym nazwaniu pobrzmiewał ambiwalentny stosunek do PAN-owskiego instytutu, który jak wiadomo - powstał pod koniec lat czterdziestych, aby po marksistowsku przekształcać polskie literaturoznawstwo. W latach, w których się w nim pojawiłem, zapomniano (młodsi) lub chciano zapominać (starsi), o tej marksistowskiej genezie. Nie dość tego. Wielu prominentnych wtedy badaczy, np. Sławiński i Głowiński oraz ich krag, promowało wówczas, w wystapieniach i artykułach, upowszechniający się w humanistyce, a więc i w nauce o literaturze, zwrot strukturalistyczny, poddawany bezskutecznie krytyce przez niedobitków marksizmu. Zatem „iblowską wtyczkę" objaśniałem sobie też pozytywnie, jako próbę promowania nowej metodologii, której myśl zaczynała się pojawiać i u nas w Łodzi, wbrew filologicznym tradycjonalistom $z$ kręgu starej polonistyki.

Tak czy tak, podczas regularnych bytności w warszawskim Pałacu Staszica poznałem wiele literaturoznawczych znakomitości oraz ich prace i książki. Nawiązałem też miłe przyjaźnie (wspominam $z$ sentymentem życzliwość i koleżeńskie wsparcie doc. Aliny Brodzkiej, potem niezadługo z tytułem profesorskim). Choć 
czułem się wciąż nieco onieśmielony, chodząc po iblowskich zaułkach pierwszego piętra Pałacu Staszica. Ów szacunek do tego miejsca wciąż mi towarzyszy!

Któregoś razu (w marcu 1971) kłaniałem się - jak zwykle grzecznie - przechodzącemu właśnie prof. Stefanowi Żółkiewskiemu (1911-1991). Dotąd kroczący jak batalion z rozłożonymi skrzydłami, profesor (ci, co go znali, potwierdzą tę obserwację) ledwie odpowiadał na moje grzeczne „dzien dobry”. Tym razem nieoczekiwanie się zatrzymał, zareagował na moje powitanie całym zdaniem i dodał: „Panie kolego, prosze przekazać pani Stefanii, że wybraliśmy ją właśnie dzisiaj do Polskiej Akademii Nauk". Skinąłem głową z odpowiednim dla chwili szacunkiem, a po powrocie do Łodzi natychmiast pobiegłem $z$ pociagu na ul. Narutowicza, gdzie mieszkała Skwarczyńska, i opowiadam z emocjami, co mnie właśnie w stolicy spotkało. „Phi powiedziała na to Pani Profesor - ja przecież jestem członkiem Polskiej Akademii Umiejętności! Co mi tam PAN!” Tu dodam, że członkiem korespondentem PAU Pani Profesor została w r. 1951, ale już w r. 1938, po habilitacji, powołano ją do składu Komisji Historii Literatury tej szacownej instytucji.

W roku 2012 Instytut Pamięci Narodowej opublikował w dwóch tomach, zatytułowanych Spętana Akademia, materiały partyjne z lat 1950-1987 dotyczące PAN właśnie, gdzie można poznać m.in. losy kandydatury Pani Profesor w wyborach do Akademii. Najpierw, co wynika $z$ dokumentów, propozycję uznano „za przedwczesną", bo Stefania Skwarczyńska nie dość, że - jak charakteryzowano - była pochodzenia ziemiańskiego (,z rodziny obszarniczej”), to utrzymywała też liczne kontakty (zarówno w kraju, jak i za granica) - o czym donosił odpowiedzialny za PAN tajny oficer - „Z odłamami syjonistycznymi” (!), np. z prof. Teodorem Domaradzkim z Montrealu i z prof. Heleną Więckowską, byłą dyrektor Biblioteki UŁ - „polką pochodzenia żydowskiego" (!). Tak więc - oceniały służby - „dotychczasowa działalność wymienionej może stanowić przeszkodę w powołaniu na członka PAN".

Ale jednakowoż w tej IPN-owskiej dokumentacji znajdziemy też, na dalszych stronicach, „wyniki 3 głosowań” w sprawie przyjęcia nowych członków na Wydziale I PAN w dniu 25 III 1971, podczas których kandydatura Pani Profesor, jako jedyna, przeszła w pierwszym głosowaniu $\mathrm{z}$ największą liczbą głosów! - a niektórzy inni kandydaci otrzymali wówczas po dwa głosy albo ani jednego (nazwisk nie będę wymieniał). Czyli dopiero w 1971 r. została członkiem korespondentem, a członkiem rzeczywistym cztery lata później, w 1975 roku.

W roku 1951 decyzją władz politycznych zawieszono na UŁ działalność Katedry Teorii Literatury. Nie zwolniono Pani Profesor z uczelni tylko dzięki zdecydowanej postawie jej ówczesnego rektora, prof. Jana Szczepańskiego (1913-2004). Sytuacja zmieniła się diametralnie po tzw. przełomie październikowym 1956 roku. Pani Profesor otrzymała w 1957 r. nominację na profesora zwyczajnego, Honorową Odznakę m. Łodzi i Nagrodę Rektora UŁ za osiągnięcia w pracy naukowej. A 1 X 1958 została uruchomiona ponownie działalność Katedry Teorii Literatury. Pani Profesor dostała wówczas Nagrodę Naukową m. Łodzi, rok później zaś Medal Światowej Rady Pokoju. Powołała w katedrze Zakład Wiedzy o Filmie, pierwszą uniwersytecką placówkę filmoznawczą w Polsce. W roku 1961 została członkiem Komitetu Nauk o Literaturze Polskiej PAN. Na przełomie lat 1957 i 1958 przebywała na stypendium naukowym w Paryżu.

Byliśmy w katedrze rodziną, co Pani Profesor lubiła podkreślać. Prof. Lewicki, 
który czasem przeżywał - by tak powiedzieć - indywidualistyczne chwile buntu i samodzielności (krótkie!), siadał wtedy na zebraniach na najgorszym w pomieszczeniach krześle, blisko wyjścia, a nie na fotelu przygotowanym dla niego przy biurku Pani Profesor i powtarzał półszeptem na stronie: „Atrydzi też rodzina!” Ale w prawdziwie dobrej atmosferze obchodziliśmy wszelkie mniejsze i większe uroczystości, nasze doktoraty i habilitacje, którym towarzyszyły małe przyjęcia $z$ alkoholem i gośćmi z zewnątrz - bywali u nas a to dziekani, a to czasem nawet sam rektor (pamiętam obecność prof. Stefana Hrabca 〈1912-1972〉, urodzonego w Stanisławowie, językoznawcy, również absolwenta lwowskiego Uniwersytetu Jana Kazimierza, którego kiedyś trzeba było po uroczystości odprowadzać, mitygując jego nader swobodne zachowanie na ulicy). Bywał często też zaprzyjaźniony z nami dyrektor Biblioteki UŁ - Michał Kuna (1923-1994).

Spotykaliśmy się rodzinnie $\mathrm{z}$ małą choinką $\mathrm{z}$ okazji świąt Bożego Narodzenia i Nowego Roku. Ale wtedy przedtem jechałem $z$ Panią Profesor na ul. Piotrkowską 47 do księgarni „Pegaz”, gdzie dzięki pomocy jej ówczesnego kierownika, Jana Gerańczyka (1920-2005), wybieraliśmy dla wszystkich książki „na gwiazdkę”, które potem ze swoim świątecznym wpisem, zawinięte w kolorowy papier, Pani Profesor wręczała każdemu z nas. I my też jakimś podarunkiem za te prezenty się rewanżowaliśmy. $N b$. Gerańczykowi, legendarnemu w Łodzi księgarzowi (w tej samej księgarni pracował od przedwojnia), z którym się nieco przyjaźniłem od czasów studenckich, zawdzięczam dobrostan mojej domowej biblioteki!

Goście przybywali do katedry - a przecież do Pani Profesor - z innych uczelni, ale i także $z$ całego świata. Ze Wschodu i z Zachodu. Pamiętam np., jak celebrowaliśmy przyjazd Hermanna Buddensiega (1893-1976) z Niemiec, który tłumaczył na niemiecki dzieła polskiej literatury. Ogromny, zwalisty mężczyzna z bokobrodami jak jakiś Bismarck - dość mrukliwy, może dlatego, że nie mówił po polsku ani nie rozumiał, co się do niego mówi. Choć, podobno inspirowany przez Mieczysława Jastruna, przełożył, niemieckim heksametrem nierymowanym, całego Mickiewiczowskiego Pana Tadeusza! Główną rozmówczynią tłumacza była oczywiście Pani Profesor, a towarzyszył im Kaszyński, bo też znał niemiecki. Buddensieg popatrywał na nas wszystkich $z$ wyższością, na mnie niechętnie, bo gdy wręczył mi na dworcu swoją potężną i wielka torbę, ja - zamiast ja nieść z szacunkiem - wstawiłem na wózek bagażowy i dowiozłem bez uszanowania do postoju taksówek. Wydawał regularnie periodyk „Mickiewicz Blätter”, który zapełniał głównie fragmentami przekładanego przez siebie eposu. Ktoś z nas domniemywał, że udawał, iż nie mówi po polsku, bo chciał nas lepiej poznać... Nb. jego przekład Mickiewiczowskiego dzieła na język niemiecki był piątym $z$ kolei.

W swoim czasie prawie wszyscy pracownicy katedry pisywali i drukowali w wydawanym w Łodzi tygodniku społeczno-kulturalnym „Odgłosy” (1958-1990). Jednym $z$ redaktorów naczelnych (do r. 1968) był lwowianin Wacław Biliński (1921-1999), absolwent tamtejszego I Gimnazjum Męskiego im. Mikołaja Kopernika. Wiązaliśmy się $z$ tygodnikiem trochę dla pieniędzy, uzupełniając skromne uniwersyteckie pensje, trochę dla autorskiej satysfakcji, publikując tam, co kto napisał: od wierszy, recenzji filmowych, teatralnych i literackich po utwory własne i własne przekłady (np. Świontek - przekłady wierszy Roberta Desnosa, Kaszyński zaś fragmenty Szczurzycy Güntera Grassa). A ja nawet, przez jakieś dwa, trzy lata, 
już za redakcji naczelnej Lucjusza Włodkowskiego, kierowałem w tygodniku działem kulturalnym.

Pani Profesor bodaj „Odgłosów” nie miewała w ręku, nigdy też temat naszej współpracy z tygodnikiem nie był przedmiotem jakichkolwiek komentarzy. Choć czytelnicy tygodnika i redakcja w 1972 r. uhonorowali Skwarczyńską tytułem Łodzianina Roku. W tym samym roku jej jubileusz 70-lecia urodzin czciła też z pełnym szacunkiem redakcja „Pamiętnika Literackiego” - „za zasługi dydaktyczne i naukowe na polu teorii literatury, teatrologii, historii literatury polskiej i porównawczej". Stefania Skwarczyńska przez dwa lata była członkiem komitetu redakcyjnego tego pisma. Publikowała zreszta już w tym czasopiśmie od połowy lat dwudziestych, a jej teksty ukazywały się również w „Ruchu Literackim”, wychodzącym w Warszawie od 1926 roku.

We Lwowie pod koniec drugiej wojny powstała koncepcja ideowa katolickiego czasopisma „Znak”, nad która pracowali Józef Feldman (1899-1946) i Stefania Skwarczyńska. Po wojnie wiele było działań i krzątaniny, zmierzających do osadzenia siedziby pisma w Krakowie pod redakcją naukową Feldmana. W Łodzi również, wedle słów Skwarczyńskiej, pracowano nad realizacją tego pomysłu wydawniczego. Redaktorem naczelnym miał być historyk filozofii ks. prof. dr Konstanty Michalski. „Znak” wprawdzie powstał ostatecznie w Krakowie, ale była to inicjatywa odległa od wstępnych projektów - także redakcyjno-personalnych. Tak czy tak, Pani Profesor współpracowała $\mathrm{z}$ periodykiem zamieszczając w nim nieregularnie teksty na temat literatury katolickiej (m.in. o dramatach Jerzego Zawieyskiego) w latach 1946-1949 (pisarz z kwiatami i życzeniami był na jubileuszu 40-lecia pracy naukowej Pani Profesor).

Pierwszym i najważniejszym naszym obowiązkiem w katedrze była oczywiście praca naukowa. Zatem kiedy - my młodzi - postanowiliśmy założyć własne rodziny, nie wiedzieliśmy, jak o tym zakomunikować Pani Profesor i jak ona sama na to zareaguje. Naszym narzeczonym i bliskim nie radziliśmy dzwonić do katedry w dni obecności Pani Profesor, bo jedyny telefon w katedrze stał tuż przy jej biurku. Pani Profesor uważała, że dom to dom, a praca na uczelni to wyjątkowe posłannictwo i wielki obowiązek - jakby w klasztornej klauzurze.

Ponieważ rodzinne plany nas, młodych, jakoś się zbiegały, Staszeczek, czyli tak przez Szefową familiarnie nazywany doc. Kaszyński, który na wiele mógł sobie pozwolić, był już wtedy po habilitacji, w czasie kolejnej katedralnej uroczystości, kiedy wyszli goście z zewnątrz, wstał z kieliszkiem w ręku i rozpoczął: „Pani Profesor, chciałbym, abyśmy wznieśli toast za naszą młodzież, która w najbliższym czasie zmienia stan cywilny! Bo oto pan Grześ ma ślub w sierpniu, pan Janusz w lipcu, pan Henryk w czerwcu, a nasz Jureczek w maju! Więc wypijmy za ich zdrowie i zdrowie ich przyszłych rodzin!" Pani Profesor wybuchnęła śmiechem - ot, przedni żart! i wydarzenia nieprawdopodobne przecież! - bo np. nazwany Jureczkiem dr Rozental w katedrze od wielu lat, w dojrzałym przecież wieku, był uznawany za „starego kawalera” bez małżeńskiej przyszłości. A młodzi nic nigdy nie wspominali! Zatem to tylko „anegdota na rauszu” docenta na koniec wieczoru - uznała Pani Profesor, po czym rozjechaliśmy się do domów w dobrych humorach, choć my, młodzi, z niepokojem! Bo my rzeczywiście planowaliśmy małżeństwa - Henryczek w czerwcu, Janusz w lipcu, a ja w sierpniu (!). Tak się jakoś zbiegło. 
Po powrocie we wrześniu na nowy rok akademicki, już po wszystkim, sprawy odeszły w przeszłość, nie było potrzeby o tym szczegółowo informować. Mimo to Pani Profesor w związku z naszymi ślubami nie przeszła jednak do porządku dziennego. Dowiedziawszy się o nich, postanowiła obdarować nas prezentami (wybranymi przez nas samych) na nową drogę życia! „Trzeba się będzie umówić zaraz - mówiła - na wspólne wyprawy do sklepu". Jak było z Henrykostwem i Januszostwem, dokładnie nie wiem. Coś tam zapewne w prezencie dostali. Ja i Irena, moja żona, też umówiliśmy się na taka wyprawę $z$ Panią Profesor. Ja spięty, Irena jeszcze bardziej. W taksówce wiele nawet nie rozmawialiśmy. Zajechaliśmy z Panią Profesor pod „Magdę”, sklep z artykułami gospodarstwa domowego przy rogu Jaracza i Piotrkowskiej. Zaraz po wejściu Pani Profesor ogłosiła: „Chcielibyśmy kupić jakiś piękny prezent, bo oto ci młodzi, dopiero po ślubie, niczego nie mają, i proszę nam coś zaproponować!" Sklep rzeczywiście był dobrze zaopatrzony, więc wybraliśmy sobie, z akceptacja fundatorki, wieloczęściowy serwis obiadowy, Pani Profesor zapłaciła i, wciąż pod wrażeniem, wróciliśmy do domów. Serwis służył nam przez całe lata. Do dziś w domu pozostały już tylko fragmenty - waza do zupy i stylizowana solniczka, które ochraniamy z żoną z największym staraniem, jakby to były jakieś etruskie naczynia, uratowane $\mathrm{w}$ wykopaliskach pod Viterbo. Tu na marginesie: Pani Profesor przecież nader często nas rozpytywała podczas spotkań, „jak tam w domu”, ,jak sobie radzicie" itp. Uważnie słuchała odpowiedzi, wiadomo też było, że w trudnych, a wyjątkowych sytuacjach pożyczała potrzebującym pieniądze.

Katedra była dla mnie (ale i dla wszystkich młodych) także szkołą życia, w której poznawałem nie tylko etykietę uniwersytecką, zasady funkcjonowania w wielopokoleniowym zespole, lecz również normy życia i obycia na co dzień, w najrozmaitszych sytuacjach: od „zachowania sie przy stole” po wystapienia publiczne. Przez katedrę przewijało się mnóstwo gości z zagranicy (od Moskwy po Montreal), oczywiście też z całej Polski, w różnym wieku, z rozmaitymi biografiami i tradycjami kulturowymi, nierzadko trzeba było rozmawiać w obcych językach. Jan Józef Lipski, profesor IBL-u, w jakiejś rozmowie ze mną wytykał nam, łodzianom, ale bodaj życzliwie, etykietę prawdziwie ziemiańsko-galicyjską! Może i coś w tym było, bo oficjalnie, także przy studentach i w bardziej uroczystych sytuacjach, Pani Profesor zawsze zwracała się do nas pełnymi tytułami, od magistra po profesora, a jeszcze częściej, jeśli któryś z nas sprawował oficjalne funkcje. Oczywiście obowiązywał też zwyczaj całowania w rękę Pani Profesor i innych kobiet-gości przy powitaniu.

Ale któregoś dnia niespodziewanie zostałem - niestety - ,żmiją wyhodowaną na własnej piersi”! Jak wspominałem, my, młodzi, opiekowaliśmy się katedralnym księgozbiorem. Gdy przychodziły pocztą paczki z książkami, rozpakowywaliśmy je, opisywali, wpisywali do rejestru ksiegozbioru, opisywali rachunki, naklejali numery i wstawiali na półki. Ja właśnie, już mocno w katedrze zadomowiony, trafiłem na taką sytuację. Listonosz przyniósł pakunek, podpisałem mu stosowną specyfikację i zabrałem się do rozwijania paczki i oglądania książek. W tym czasie pojawiła się ni stąd, ni zowąd jedna $z$ ówczesnych doktorantek Pani Profesor i zajrzała mi przez ramię. Gdy ujrzała jedną z książek, natychmiast chciała ją przeglądać i czytać jako niezbędną w przygotowywanym przez siebie doktoracie! „Wezmę ją do czytelni bibliotecznej na drugim piętrze i zaraz przyniosę" - prosiła. Tego nie wolno mi było 
zrobić pod żadnym pozorem, książka nie mogła opuścić katedry bez opieczętowania, wpisania do rejestru, naklejenia odpowiedniego numeru i bez rewersu! A ja to wszystko lekkomyślnie zlekceważyłem, machnąłem ręką, bo wiedziałem, komu tę książkę daję, przecież tylko „na trochę” i zaraz dostanę ją z powrotem. A tu katastrofa - przybyła za chwilę Pani Profesor, jakoś wcześniej tego dnia, i też zaczęła oglądać książki z zainteresowaniem, patrzyła w rachunek i szukała egzemplarza, który ją oto niestety również zainteresował. Nie ma! Gdzie jest?! Musiałem się przyznać! Pobiegłem natychmiast do czytelni, książkę przyniosłem, zaraz ją Pani Profesor podałem! No i usłyszałem ostrą reprymendę, w której pojawiło się to nieszczęsne zdanie o „żmii”. Nie było nawet sposobu, aby to wszystko racjonalnie objaśnić. Nie pomogła też ta katedralna doktorantka, mgr Elżbieta Wróblewska (1938-1980), która próbowała wtrącić swoje usprawiedliwienie. „Żmija” i „panem magistrem” (a nie „panem Grzesiem”!) byłem tego dnia przez kilka godzin. Potem - bo książka przecież nie zginęła, zaraz wróciła - trzeba było zasiąść do maszyny, odpowiedzieć na pismo panu dziekanowi i żyć dalej! Elżbieta zaś po kilku latach (1971) uzyskała doktorat, pod promotorską opieką Pani Profesor, na podstawie rozprawy o poetyce immanentnej krakowskiej awangardy. I rzecz poszła w niepamięć!

Ja, na nic się nie oglądając, znów wziąłem się za doktorat, bo tego wymagały okoliczności mojego zatrudnienia. Jako przedmiot rozprawy wymyśliłem sobie polski futuryzm - wprawdzie pisano już trochę na ten temat (Helena Zaworska, Edward Balcerzan), ale monografia nie istniała. Wciąż aktywny był dawny współtwórca futuryzmu w poezji, teraz zaś jedyny świadek, Anatol Stern (1899-1968): ładził swoje futurystyczne ekscesy we wznowieniach; ze Skwarczyńską znał się osobiście, a i ja go dzięki temu poznałem; pożyczał mi maszynopis swojej niewydanej wtedy powieści Namiętny pielgrzym. W Łodzi jeszcze dożywał swoich dni Stanisław Brucz (1899-1978), ale niewiele już pamiętał ze swojej futurystycznej młodości. A Aleksander Wat (1900-1967) był właśnie zmarł w Paryżu.

Zaakceptowała od samego początku ten pomysł Pani Profesor, nad czym się wtedy nie zastanawiałem. Podczas egzaminu magisterskiego $z$ jej udziałem znaczna jego część wprawdzie dotyczyła nowatorskiej poezji międzywojennej, ale przecież Skwarczyńska, jako historyk i teoretyk literatury, żyła w świecie wielkich polskich romantyków, im poświęciła swój doktorat, o nich pisała, ich twórczość interpretowała, od samego poczatku swej naukowej kariery, najpierw jako studentka, potem doktor i docent na lwowskim Uniwersytecie Jana Kazimierza, pod kierunkiem wielkiego monografisty Mickiewicza i Słowackiego - Juliusza Kleinera! Więc skąd ta aprobata dla futuryzmu?! Bez pytania w rodzaju: „Panie Grzesiu, czy warto tym futurystom poświęcać parę lat życia na monografię?" (Nie znam niemieckiego, a właśnie wtedy ukazała się monografia Christy Baumgarth $\mathrm{z}$ historią włoskiego futuryzmu 〈Geschichte der Futurismus, 1966〉 i Pani Profesor poświęciła potem kilka spotkań u siebie w domu, tłumacząc dla mnie spore fragmenty tej cennej książki.)

Odpowiedź bodaj znalazłem po latach, dopiero co. Oto Andrzej Franaszek w pierwszym tomie swojej znakomitej biografii Herberta (2018) wspomina Skwarczyńska! Młody Zbyszek w rodzinnym Lwowie, po maturze (już pod okupacją rosyjska), w zajętym potem przez Niemców mieście, rozpoczyna studia polonistyczne na tajnych kompletach, zamkniętego, ale wtedy działającego w konspiracji, Uni- 
wersytetu Jana Kazimierza (ze wszystkimi uczelnianymi rygorami). Wśród wykładowców nazwiska wybitnych filozofów, lecz także polonistów - Stanisława Łempickiego, Witolda Taszyckiego, Marii Dłuskiej i właśnie Stefanii Skwarczyńskiej, docenta po pierwszej w Polsce habilitacji teoretycznoliterackiej w 1937 roku!

Na podstawie zachowanych notatek poety Franaszek podaje, że Herbert brał udział w wykładach Skwarczyńskiej o polskiej poezji lat 1918-1939! W „solidnym kajecie" zachowanym w archiwum poety - podaje monografista - znajdują się notatki o poezji schyłku Młodej Polski, o przełomie po Wielkiej Wojnie i o poezji futurystów, Jasieńskiego, Wata i Sterna, „opatrzonych - pisze Franaszek - słowem "Żydzi". Także zreszta przy nazwisku Tuwima znajduje nie do końca jasną Herbertowską notatkę „zag. Żydów swoboda języka”). Potem o Leśmianie, skamandrytach, Peiperze i Przybosiu z podkreśleniem, że u nich „istotny był intelektualizm”, a nie „katarynka uczuciowa”, o Czechowiczu, wileńskich Żagarach i „wybitnym” Czesławie Miłoszu.

„Wykład był - ocenia Franaszek - jak na konspiracyjne warunki zaskakująco obszerny [...], a Herbert teraz szybko nadrabiał zaległości z literatury współczesnej”. Wszystko to znaczy, że Pani Profesor nie tylko dobrze znała dokonania polskiej awangardy międzywojennej, że futuryzm rozpoznawała in statu nascendi i że próbowała interpretować funkcje i motywy futurystycznych eksperymentów językowych na wiele lat przed tym, jak stały się one przedmiotem zainteresowania literaturoznawców (sama przecież napisała i opublikowała doktorat o ewolucji obrazów u Słowackiego).

Wskazywała na genezę futuryzmu. Gdy po dziesiątkach lat od czasów lwowskich rozmawiałem z Panią Profesor o języku wierszy Tuwima, wynikało - podobnie jak pośrednio z zapisku Herberta - że według Skwarczyńskiej język poetycki oraz eksperymentalna swoboda w użyciu polszczyzny, swoista bezceremonialność samego Tuwima oraz futurystów uwarunkowane były także, być może, ich etnicznym pochodzeniem. Dyskusyjna chyba to opinia - mogę dzisiaj powiedzieć - zwłaszcza gdy weźmie się pod uwagę natężenie lingwistycznych eksperymentów i falę buntów wobec tradycyjnych formuł języka poetyckiego w całej awangardowej Europie, czy to rosyjskiej, czy to niemieckiej, czy francuskiej. Choć, z drugiej strony, trzeba przypomnieć, że w całej Europie nowatorscy artyści pochodzenia żydowskiego rzeczywiście odgrywali istotną rolę! Jednakże taki punkt widzenia jak w notatce Herberta nie pojawił się już potem w naszych seminaryjnych analizach i dyskusjach o futuryzmie $z$ udziałem Pani Profesor.

Dzięki rekonstrukcjom Franaszka poznałem niektóre szczegóły udziału młodej Skwarczyńskiej w tajnym nauczaniu wykładowców Uniwersytetu Jana Kazimierza w okresie niemieckiej okupacji Lwowa. Nigdy zresztą na ten temat $\mathrm{z}$ nią nie rozmawiałem. Ani nigdy nie było miejsca przy katedralnym czarnym stoliku, podczas wspólnych „rodzinnych" pogwarek w jej gabinecie, ani także w jej domu przy kawie, na lwowskie wspominki, choć mogłoby się wydawać to naturalne wśród profesury wywodzącej się ze Lwowa. Być może to był temat tabu, nazbyt osobisty, bo przecież w dokumentach, w rubryce „miejsce urodzenia” wpisywano wtedy urzędowo „Lwów (ZSRR)"! A może odcięcie lwowskiej pępowiny było dla byłych Kresowian zbyt bolesną traumą?

Ta część międzywojennej biografii godna jest jednakowoż oddzielnej rekonstruk- 
cji historycznej. Tu tylko dopowiem, że po habilitacji w 1937 r. na lwowskiej uczelni, doc. Skwarczyńska prowadziła tam, do r. 1939, gościnnie wykłady z teorii literatury i $z$ literatury francuskiej. Była to druga $\mathrm{w}$ dziejach akademickich $\mathrm{w}$ Polsce habilitacja dla kobiety! Dwa lata wcześniej, w r. 1935, habilitację z historii sztuki uzyskała Karolina Lanckorońska (1898-2002). Ale pierwsza z literaturoznawstwa.

Wybuch Wielkiej Wojny zastał Skwarczyńską w rodzinnym majątku we wsi Dąbrówka koło Sanoka (spadek Strzelbickich po śmierci w 1908 r. matki, Marii ze Ścibor-Rylskich; malowniczy dwór wyremontowano, a ziemia poszła w dzierżawy), gdzie zamieszkali w r. 1918, kiedy ojciec, Mieczysław Strzelbicki (1857-1922), otrzymał stanowisko starosty w Nowym Saczu. Poprzednio pełnił ten urząd w nieodległej od Lwowa Kamionce Strumiłowej, gdzie 17 XI 1902 urodziła się Stefania. Uczyła się ona do 1921 r. najpierw w 8-letnim klasycznym gimnazjum żeńskim w Nowym Sączu, a potem przez trzy lata do matury, w Sanoku, w Gimnazjum Męskim (współredagowała tam w 1921 r. ambitnie pisemko „Jaskółka”). Wspominała Pani Profesor u schyłku swojego życia:

Trzyletni pobyt w gimnazjum sanockim był dla mojego rozwoju intelektualnego i dla mojego rozkochania w literaturze wyjątkowo przychylny. Jest to niewatpliwie zasługa moich wybitnych tam nauczycieli, ale i także gimnazjalnej biblioteki - wyjątkowo wspaniałej, obfitej i mądrze zorganizowanej. Przede wszystkim dysponowała one poważnym zasobem dzieł literackich i dzieł o literaturze i kulturze i to nie tylko dziełami polskimi. [...] Mieliśmy do dyspozycji dzieła polskie oraz łacińskie i greckie, jak dzieła poetów niemieckich; znajdowały się tam także książki francuskie.

Zaraz po maturze, od nowego roku szkolnego, Skwarczyńska podjęła studia na Wydziale Filozoficznym Uniwersytetu Jana Kazimierza we Lwowie. Gdy wybuchła druga wojna, trzeba było więc pospiesznie wracać do mieszkania lwowskiego. Ale 23 IX 1939, po porozumieniu z Niemcami, to Rosjanie zajęli miasto. We Lwowie znalazły się kobiety z trójką małych dzieci, bo i maleńki chrześniak Pani Profesor Krzyś Jakubowski (1937-2011), syn Jana Zygmunta Jakubowskiego, późniejszego profesora Uniwersytetu Warszawskiego (1905-1975; w czasie drugiej wojny więźnia Auschwitz i Buchenwaldu); Krzysztof po wojnie, już jako profesor geologii, był m.in. dyrektorem Muzeum Ziemi PAN. Nie wiadomo, co działo się wtedy ze starszym bratem Pani Profesor, Marianem Strzelbickim (1908-1940), żołnierzem Wojska Polskiego (ostatni list pochodził z Kozielska). Młodszy brat Stanisław (ur. 1906) zginął tragicznie 5 IX 1938 na manewrach. Mąż Tadeusz (1894-1978) zaś, jeszcze w sierpniu, otrzymał telegram $z$ wezwaniem do swojego garnizonu. Być może znalazł się w ówczesnym miejscu stacjonowania swojej jednostki, czyli w Łodzi?

Miasto to było oswojone przez rodzinę od jakiegoś czasu - major Tadeusz Skwarczyński w 1932 r. otrzymał tu ważne stanowisko w garnizonie. Jego żona zaś jak już wspominałem - podjęła nauczycielskie obowiązki w tutejszym Gimnazjum im. Elizy Orzeszkowej, a w 1938 r. została mianowana profesorem nadzwyczajnym łódzkiego oddziału Wolnej Wszechnicy Polskiej (powołanej w r. 1928), w którym miała kierować Katedrą Historii i Teorii Literatury. Aktywna na wielu polach, została też redaktorem inicjowanych właśnie „Prac Polonistycznych” (do września 1939 wyszły trzy zeszyty). Działała także w Towarzystwie Polonistów Rzeczypospolitej, gdzie kierowała łódzkim oddziałem.

W Łodzi przyszła na świat, w czerwcu 1935, druga córka Skwarczyńskich Joanna (czyli Janusia, jak ją familiarnie nazywano, 1935-1948). Pani Stefania 
postanowiła więc przedrzeć się ze Lwowa przez zieloną granicę - linię demarkacyjną obu okupantów - najpierw do Dąbrówki, a potem do Łodzi. Stamtąd jednak, nie zastawszy męża (podobno jego jednostkę wyznaczono do obrony Lwowa), wróciła z najpotrzebniejszymi rzeczami, zabranymi $z$ mieszkania, oraz z nadzieją na rychłe spotkanie $z$ mężem i uporządkowanie lwowskich spraw rodzinnych.

Powrót przez pół Polski, Kraków i Przemyśl mógł się zakończyć tragicznie. I rzeczywiście - Skwarczyńska, zatrzymana na ustalonej przez okupantów granicy na Sanie, poddana została przez Rosjan śledztwom i przesłuchaniom. Opowiadania o tym dramatycznym powrocie wysłuchałem kiedyś podczas jakiejś chwili zwierzeń o przeszłości (prawdę mówiąc - zdarzały się one bardzo rzadko). „Przesłuchujący oficer zaczą kpić ze szkaplerza ze świętym wizerunkiem, który nosiłam na szyi na srebrnym łańcuszku: - Co, myślisz, że ten zabobon cię uratuje?! Zobaczymy! - Wstał i otworzył drzwi. - No, idź do tego swojego Lwowa! Idź! - Nie wiedziałam - opowiadała Pani Profesor - co się ze mną za chwile stanie... Ale wyszłam... i czekałam na strzał z pistoletu, który widziałam podczas przesłuchania na biurku! Przeszłam bardzo powoli sień, znalazłam się na dworze. A strzał nie nastapił! Byłam więc wolna, wolna! I tak dotarłam do rodzinnej Dąbrówki”. Tam dowiedziała się, że Tadeusz dostał się do niemieckiej niewoli (osadzony w oflagu dla jeńców do końca wojny). A wieść o Marianie, bracie Skwarczyńskiej, przyszła dopiero po paru miesiącach: przetrzymywany najpierw przez Rosjan w Kozielsku, zginął rozstrzelany wraz z tysiącami Polaków i żołnierzy w 1940 r. w Katyniu.

Tego samego roku, w czasie okupacji rosyjskiej, zmieniono patronat uczelni, nadając jej imię Iwana Franki, a Pani Profesor podjęła tam z poręczenia Kleinera wykłady - jak już pisałem - jako docent od października 1939 do kwietnia następnego roku.

W nocy z 13 na 14 IV 1940 wraz z teściową i trójką małych dzieci (obie córki i chrześniak Krzyś) została przez NKWD aresztowana i zesłana „na roboty” do Kazachstanu (wieś Michajłówka w pobliżu Ałma-Aty). Ale dzięki interwencji - jak się często powtarza - Kleinera, Pani Profesor wraz z dziećmi, po kilku miesiącach zesłania (trwającego od kwietnia do listopada 1940), przez Moskwę wróciła do Lwowa. Swoje przeżycia $\mathrm{z}$ tych strasznych miesięcy odnotowała na gorąco w zapiskach „kazachstańskiego dziennika”, który w obszernych fragmentach - pt. Byłam niepodległa - opublikowałem na łamach „Verte”, łódzkiego dodatku do „Gazety Wyborczej” (1993, nr 99).

Pisze Skwarczyńska w swoim wspomnieniu:

I znów profesorowi Kleinerowi udało się wyprosić dla mnie powrót do uniwersyteckiej pracy, oczywiście nadal w charakterze docenta, a nie profesora. Ale i to najzupełniej wystarczało na utrzymanie sporej rodziny, a nawet jej powiększenie. A to w ten sposób, że przyjęło się do czasu za swoją dziewczynkę, która wraz ze swoją nieco starszą siostrą uciekła z Kazachstanu po śmierci z głodu swej matki, a która nie miała we Lwowie nikogo, kto zechciałby ją przytulić.

Potem, w czasie okupacji niemieckiej, to Pani Profesor pomagała Kleinerowi, gdy ukrywał się przed Niemcami $z$ fałszywym ausweisem na nazwisko Jan Zalutyński; umieszczono go z dziećmi najpierw w chłopskim domu obok dworu w Dąbrówce, potem ze względów bezpieczeństwa przenoszono też do kolejnych „kryjówek”.

Podobnymi działaniami - wraz z Jerzym Kuryłowiczem czy z Ryszardem Gansińcem - ratowała także życie innych Polaków pochodzenia żydowskiego. A czas 
niemieckiej okupacji Lwowa był w biografii Skwarczyńskiej nader dramatyczny. Pracowała w Instytucie Badań nad Tyfusem Plamistym prof. Rudolfa Stefana Weigla (1983-1957) jako jedna $\mathrm{z}$ administratorek i karmicielka wszy (formalnie pracownicą instytutu była również jej najstarsza córka, Maria). Nauczała na tajnych kompletach konspiracyjnego uniwersytetu (spotkania odbywały się też w jej mieszkaniu), działała w podziemiu ZWZ i AK (pseudonimy „Maria” i „Jarema”) oraz w organizacji pomocy Żydom „Żegota”. Zredagowała wydane wówczas tomiki poetyckie z wierszami różnych polskich autorów - Wierne płomienie i Śpiew wojny: ten drugi we współpracy z Mirosławem Żuławskim. (Przechowywaliśmy je starannie w archiwum Katedry Teorii Literatury, więc miałem je w ręku - dziś są zapewne w zbiorach biblioteki Wydziału Filologicznego UŁ.) Współredagowała także konspiracyjne czasopisma „Służba Państwu” i „Kobieta w Walce” - żeby wskazać tu na najważniejsze wtedy jej obowiązki $z$ wyboru.

W ostatnio wydanej monografii biograficznej Profesor Weigel i karmiciele wszy (Warszawa 2018) Mariusz Urbanek sugeruje, że to sam wynalazca szczepionki przeciw tyfusowi, szef instytutu, jako szczególnie potrzebny rosyjskim okupantom (a potem też Niemcom), przyczynił się przede wszystkim, swoimi interwencjami u Rosjan, do zwolnienia Skwarczyńskiej i jej najbliższych ze zsyłki kazachstańskiej. (W lutym 1940 wizytował instytut szef ukraińskiej partii komunistycznej Nikita Chruszczow.) Kleiner mógł co najwyżej w tym jedynie pośredniczyć - u Weigla, swego uniwersyteckiego kolegi - bo, jak można przypuszczać, jego osobiste starania w NKWD nie na wiele by się zdały. (Skwarczyńska, podobnie jak setki lwowian, była przesłuchiwana przez NKWD na kilka tygodni przed aresztowaniem.)

Być może jakąś rolę w tej akcji - to już moje dopowiedzenie, bo nigdy z Panią Profesor na ten temat nie rozmawiałem - odegrała także Wanda Wasilewska (o czym się też często wspomina w biografiach Skwarczyńskiej), wtedy wpływowa deputowana do Rady Najwyższej ZSRR. O zasługach i roli prof. Weigla w ratowaniu mieszkańców Lwowa w czasie okupacji pisała po latach również córka Pani Profesor, prof. Maria Olszewska, w czasopiśmie PAN „Academia” w 2007 roku.

Dziś chyba nie da się rozstrzygnąc jednoznacznie, kto najskuteczniej i jak przyczynił się do uratowania Skwarczyńskiej z dziećmi z kazachstańskiej zsyłki. Może powinniśmy przyjąć, że Kleiner, powszechnie uznana i ceniona postać lwowskiej uczelni, mógł zwracać się o pomoc do wielce wpływowej Wandy Wasilewskiej, a Weigel, też uniwersytecki profesor, szef „strategicznego” instytutu, ze swojej strony również mógł wspierać starania o uwolnienie młodej, wybitnej uczonej.

Tu dopowiedzmy: młoda docent podjęła pracę $\mathrm{w}$ instytucie Weigla wraz z setkami zaangażowanych tam karmicieli wszy. Nie była szeregową karmicielką, pełniła także (chwalona przez Weigla) niektóre funkcje administracyjne. W czasie niemieckiej okupacji przewinęło się przez instytut ponad 500 osób, m.in. Stefan Banach, Jerzy Broszkiewicz, Józef Chałasiński, Leszek Elektorowicz, Zbigniew Herbert, Artur Hutnikiewicz, Zdzisław Stieber i Mirosław Żuławski (w r. 1971 jego syn, Andrzej, nakręcił film Trzecia część nocy, którego kilka sekwencji rozgrywa się m.in. w lwowskim instytucie prof. Weigla - choć nazwa miasta nie pada w filmie ani razu; realia tych fragmentów pozwalają nam po części zapoznać się z działalnością instytutu i z pracą karmicieli wszy).

$Z$ prof. Stieberem, wybitnym językoznawca, nagradzanym po wojnie wieloma 
międzynarodowymi odznaczeniami, również m.in. organizatorem naukowych placówek językoznawczych na nowo powstałym po wojnie Uniwersytecie Łódzkim, Pani Profesor blisko się przyjaźniła. To on pomagał jej po 1945 r. częściowo odtwarzać utracony w czasach wojny naukowy księgozbiór domowy. Na jednej z książek zdobytych przez niego w antykwariacie, $n b$. autorstwa Pani Profesor, znajduje jej dopisek ołówkiem „dar od Zdzisia”.

Rozmawiałem kiedyś z Panią Profesor na ten temat, zainteresowany jej niedużą, ale cenną naukowo biblioteką w domu. „Czy udało się coś ocalić z lwowskich ksiązek?” - zapytałem niemądrze. „Kiedy w nocy aresztowało nas NKWD - opowiadała Pani Profesor - jak mogłam myśleć o książkach?! Udało mi się spakować pośród rzeczy najpotrzebniejszych dzieciom tylko ślubny serwis obiadowy, którego poszczególne części w najtrudniejszych miesiącach zesłania mogłam wymieniać na mleko dla maluchów".

Po zakończeniu wojny, 3 V 1945, Stefania Skwarczyńska przybyła przez Kraków wraz z rodziną do Łodzi, wysłużoną ciężarówką z resztkami domowego, ale cennego dobytku (były to też niektóre mniejsze, niebanalne meble, rodzinne portrety, które tworzyły potem w Łodzi niepowtarzalny styl jej gabinetu), na zaproszenie władz rektorskich powstającego uniwersytetu, na którym otrzymała etat profesorski. Zamieszkała z mężem i córkami w skromnym mieszkaniu przy ul. Julianowskiej 22.

Tu - by tak powiedzieć - z marszu, przyjęła współpracę z doktorem Uniwersytetu Jana Kazimierza Juliuszem Salonim (1891-1963), który postanowił wznowić w Łodzi przedwojenne czasopismo literaturoznawcze „Życie Literackie” (do r. 1939 wyszły trzy roczniki). Periodyk ten - przemianowany wkrótce na „Zagadnienia Literackie” - miał służyć „naukowym roztrząsaniom teoretycznoliterackim bez względu na kierunek ideowy i postawę filozoficzną autorów artykułów”. W ciagu najbliższych lat, do grudnia 1948, ukazały się jeszcze niepełne trzy roczniki tego wznowionego dwumiesięcznika. Wśród autorów byli m.in. Stanisław Adamczewski, Andrzej Boleski, Kazimierz Budzyk, Roman Ingarden, Juliusz Kleiner, Zenon Klemensiewicz, Janina Kulczycka-Saloni, Eugeniusz Sawrymowicz, Zdzisław Stieber, Stefan Szuman, Zygmunt Szweykowski, Karol Zawodziński i Stefan Żółkiewski. Tę listę swietnych postaci polskiej humanistyki uzupełniały nazwiska przedstawicieli rosyjskiej szkoły formalnej: Wiktora Szkłowskiego, Borysa Tomaszewskiego i Wiktora Żyrmunskiego, których prace ukazały się w przekładzie Franciszka Siedleckiego.

Debiutował bodaj w tym dwumiesięczniku Jan Trzynadlowski (1912-1995), który objął wtedy również stanowisko starszego asystenta Skwarczyńskiej na Uniwersytecie Łódzkim. Przybył on ze Lwowa (urodził się tam) tym samym transportem co Pani Profesor, jako magister, absolwent konspiracyjnego Uniwersytetu Jana Kazimierza. Po doktoracie na temat surrealizmu, napisanym w Łodzi pod kierunkiem Pani Profesor, w 1950 r. przeniósł się do Wrocławia, gdzie po latach uzyskał etat i tytuł profesora zwyczajnego na uniwersytecie (1966); pełnił też przez jakiś czas funkcję dyrektora Zakładu Narodowego im. Ossolińskich, instytucji - jak wiadomo - przeniesionej ze Lwowa w r. 1945 (teraz tylko z częścią cennych zbiorów, porzuconych na Dolnym Śląsku przez Niemców w czasie odwrotu). Przez 20 lat był sekretarzem generalnym Wrocławskiego Towarzystwa Naukowego; współpracował 
z Panią Profesor przez długie lata, m.in. jako współredaktor czasopisma „Zagadnienia Rodzajów Literackich".

Był częstym, lubianym i dowcipnym gościem naszej katedry w Łodzi i ja także osobiście asystowałem mu i sekretarzowałem przy bardzo wielu jego obowiąkach, które przejął po śmierci Pani Profesor (np. w redakcji „Zagadnień Rodzajów Literackich”, w przewodniczeniu Komisji Poetyki i Stylistyki Słowiańskiej Międzynarodowego Komitetu Slawistów, w organizowaniu konferencji tej komisji we Wrocławiu we wrześniu 1985). Na jego pogrzebie, czego byłem świadkiem, przemawiało nad trumną 17 mówców w imieniu rozmaitych instytucji wrocławskich, bo Trzynadlowski wytworzył sobie w tym mieście walor osoby-instytucji. Ale oto, już po jego smierci, w czasach ustrojowej odnowy, niespodziewanie miało się okazać (piszę to według informacji z Wikipedii), że przez kilkanaście lat był tajnym współpracownikiem Służby Bezpieczeństwa o pseudonimie „Konrad”! Dla wszystkich, którzy go znali i lubili, brzmi to jak kalumnia i szczególnie ponury żart! Pan Jan - tajnym agentem służb specjalnych! I jakąż rolę tam pełnił?! Trudno mi w to wierzyć! Dobrze, że prof. Skwarczyńska tego nie dożyła!

Wracając do przyjętej w tym tekście chronologii: jeździłem przez dwa lata na seminaria i spotkania doktoratowe do IBL-u z poznawczą korzyścią i z ciekawością. Prowadziła je dwójka dopiero co wypromowanych docentów po habilitacjach. Taka dwójpolówka (łódzka i warszawska), którą uprawiałem, była wielce inspirująca. Wreszcie, po czterech latach, prace pod „doktorskim” tytułem Futuryzm $w$ Polsce na tle ówczesnych prąów literackich ukończyłem w r. 1971 (ukazała się ona drukiem w 1974 r. w Ossolineum dzięki aprobacie i pozytywnej opinii prof. Janusza Sławińskiego). Obrona, po uwzględnieniu wszelkich formalności, odbywała się w lutym 1972, oczywiście w Instytucie Badań Literackich PAN. Wyznaczono dwóch recenzentów: prof. Artura Hutnikiewicza $z$ Uniwersytetu Mikołaja Kopernika w Toruniu (1916-2005; urodzony we Lwowie!) i doc. dr. hab. Michała Głowińskiego z IBL. Na prośbę Pani Profesor - bo, formalnie rzecz biorąc, przy doktoracie wystarczało dwóch recenzentów - dołączono też będąca tuż po habilitacji łodziankę z Katedry Teorii Literatury Teresę Cieślikowską („chcę pokazać naszą Teresę w Warszawie” - objaśniała Skwarczyńska). Przewodniczyć egzaminowi miał sam prof. Kazimierz Wyka, dyrektor IBL-u i profesor Uniwersytetu Jagiellońskiego.

Egzamin odbywał się w lutym, w środku zimy, z taką komplikacją, że tego dnia zaplanowano w Warszawie (a właściwie w Konstancinie) konferencję członków Polskiej Akademii Nauk, zatem obronę doktoratu przeniesiono na późne popołudnie, a zamiast Wyki przewodniczył doc. dr hab. Stefan Treugutt (1925-1991). Trochę mnie to zbiło z pantałyku, bo spodziewając się Wyki, zawołanego kibica Cracovii, rozpoznawałem - pół żartem, pół serio - na okazję egzaminu miejsce tej drużyny w tabeli pierwszej ligi i jej ostatnie zwycięstwa! (Profesor miał być znany z tego rodzaju pytań na koniec egzaminu!)

Przyjechała ze mną do Warszawy żona Irena (w zaawansowanej ciąży; za dwa miesiące - w maju - urodziła pierworodnego Michała!) i pozostawała pod opieka naszej przyjaciółki Broni Stolarskiej (ur. 1944; razem zdobywaliśmy maturę w VI LO im. Joachima Lelewela w Łodzi, razem studiowaliśmy na polonistyce, razem potem pracowaliśmy na Uniwersytecie Łódzkim, razem uczestniczyliśmy w filmoznawczym seminarium magisterskim prof. Lewickiego, i przyjaźnimy się od lat). Bronka na- 
pisała dobry doktorat o twórczości Tadeusza Konwickiego i współpracowała z Lewickim także wtedy, gdy już na emeryturze, podjął on obowiązki profesorskie na nowo powstałym Uniwersytecie Gdańskim.

Uroczysta obrona odbyła się wedle obowiązujących reguł z pozytywnymi i jednoznacznie aprobatywnymi wnioskami (pamiętam dobre słowa siedzącego wtedy na widowni dr. Janusza Stradeckiego - m.in. monografisty „Skamandra”). Zmęczona wszystkimi okolicznościami Irena wraz z Bronką wróciły do Łodzi, a ja, też porządnie zestresowany, zapraszałem członków komisji na nader spóźniony obiad w restauracji tuż przy Pałacu Staszica.

Spotkanie było bardzo sympatyczne, Treugutt w moim imieniu (!) żartobliwie dziękował zebranym przy stole za recenzyjny i organizacyjny trud, a ja - usatysfakcjonowany, lecz na wpół żywy po trudach dnia - mogłem się tylko uśmiechać; duszą towarzystwa był sam przewodniczący komisji. Nie pamiętam wszystkich świetnych anegdot i żartów - oprócz jednej opowieści: Michał Głowiński, który dopiero co wrócił $\mathrm{z}$ Kopenhagi, opowiadał o swoich wrażeniach $\mathrm{z}$ obejrzanego tam musicalu Jezus Chrystus Superstar i była to opowieść tyleż dowcipna, co - z religijnego punktu widzenia - ryzykownie obrazoburcza. Ale Pani Profesor przyjęła ją tak, jak należało - śmiejąc się i bawiąc się tym „wynaturzeniem” swobód zachodniej kultury.

Do Łodzi wracałem więc jako doktor nauk humanistycznych, do swoich zwyczajnych obowiązków dydaktycznych. Ale czekały na mnie też inne powinności. Zaczęto reaktywować działalność Międzynarodowego Komitetu Slawistów. Po śmierci wybitnego literaturoznawcy prof. Wiktora Winogradowa, członka radzieckiej Akademii Nauk, funkcja przewodniczącego Komisji Poetyki i Stylistyki Słowiańskiej przypadła - decyzją MKS-u z r. 1970 - Stefanii Skwarczyńskiej. W tej sprawie podróżowali do Łodzi szefowie międzynarodowego i polskiego komitetu. Skwarczyńska przyjęła propozycję, uznając swoje nowe obowiązki za zaszczyt, a ja z jej poręki zostałem powołany na stanowisko sekretarza komisji. Nieczynny dotąd w dużym stopniu MKS - jego obrady w pamiętnym 1968 roku, w sierpniu w Pradze, kończyły się w dramatycznych, jak wiadomo, okolicznościach „wiosny praskiej” i wkroczenia wojsk Układu Warszawskiego do Czechosłowacji (uczestniczyła też w tym kongresie Stefania Skwarczyńska) - wymagał nie tylko rekonstrukcji, ale i odbudowy kluczowych funkcji.

Polsce przypadł właśnie obowiązek organizacji światowego Kongresu Slawistów w r. 1973, a komisja, której przewodniczyła teraz Pani Profesor, nie dość, że musiała odtwarzać swoją strukturę, to podjęła się także organizacji posiedzenia naukowego w Warszawie, w sierpniu 1972. Działania rozpoczęliśmy - co zrozumiałe na wiele miesięcy przed tą datą. Zrekonstruowaliśmy skład komisji (liczyła ona wtedy kilkudziesięciu członków, dosłownie $z$ całego świata - od Kairu po Toronto, od Oslo po Edmonton, od Lwowa po Oksford, od Melbourne po Sztokholm), ustaliliśmy korespondencyjnie $z$ jej członkami tematykę i zakres organizacyjny konferencji, która ostatecznie odbywała sie przez trzy dni w warszawskim Pałacu Staszica i na tamtejszym uniwersytecie. Była to konferencja na tyle udana, z licznym udziałem slawistów $z$ całego świata, że nazywano ja potem małym kongresem slawistów. W jej wyniku ukazał się w Ossolineum - jeszcze przed kongresem - pokaźny tom studiów pod redakcją Skwarczyńskiej, przygotowany z moją sekretarsko-redakcyjną pomocą: Poetyka i stylistyka stowiańska (1973). A na Kongresie Sla- 
wistów w 1973 r. mogliśmy się spotkać jeszcze raz w Warszawie z najwybitniejszymi slawistami świata, także członkami naszej komisji. Ta moja współpraca $z$ Panią Profesor trwała jeszcze dobrych kilka lat, organizowaliśmy kolejne konferencje: w Tihany (1974), Lipsku (1977) - te dwie konferencje $z$ udziałem osobistym Pani Profesor - i we Wrocławiu (1985); posiedzenia, w których uczestniczyłem, odbywały się też podczas kolejnych kongresów slawistycznych, w Zagrzebiu (1978), Kijowie (1983) i Sofii (1988).

Dla mnie samego - już po doktoracie - były to nadzwyczaj ważne wydarzenia, spotkania i doświadczenia naukowe. Dzięki nim mogłem nawiązać pożyteczne naukowo kontakty z literaturoznawcami z wielu krajów. Szczególnie zaprzyjaźniłem się z profesorem sztokholmskiego uniwersytetu, rusycystą i znawcą nowoczesnych prądów literackich XX stulecia, Nilsem Åke Nilssonem (1917-1995). Miałem w Sztokholmie dwa wykłady na temat polskiego futuryzmu, potem brałem udział w dużych slawistycznych konferencjach - w Lipsku oraz w Sztokholmie (Nobel Symposium; m.in. z Krystyną Pomorską, Jurkiem Jarzębskim i Janem Błońskim oraz z wieloma slawistami z całej Europy) na temat awangard (Slavic Literatures and Modernism, 5-8 VIII 1985). Stało się to potem podnieta do współpracy przy przygotowaniu książki o awangardach europejskich, do licznych konsultacji i kontaktów, a wreszcie do napisania Słownika europejskich kierunków i grup literackich XX wieku (dwa wydania w PWN-ie $\langle 2000,2009\rangle$, z kilkoma nagrodami). Nb. na zaproszenie naszego instytutu Nilsson bywał też $z$ wykładami w Łodzi. Już wymieniany Tadeusz Szczepański, wtedy eisensteinolog (wydał książkę o teatralnych dokonaniach tego rosyjskiego reżysera), po wywiadzie do „Odgłosów” z Nilssonem - co śmiem twierdzić - zmienił swoje naukowe zainteresowania i przeszedł, by tak rzec, całkowicie na skandynawizm. Nauczył się szwedzkiego i dziś jest najwybitniejszym polskim znawcą kinematografii i sztuki filmowej krajów skandynawskich! I autorem opasłej monografii na ten temat, dopiero co wydanej w Łodzi przez wydawnictwo PWSFTviT.

Podjęta dzięki Pani Profesor współpraca z europejskimi środowiskami naukowymi pozwoliła mi potem na kontynuowanie (1997-2010) i podtrzymanie tradycji edytorskiej i merytorycznej „Zagadnień Rodzajów Literackich” - półrocznika założonego przez Panią Profesor w 1958 roku. Jeszcze po śmierci Pani Profesor, kiedy to jej obowiązki podejmował, jako przewodniczący, Jan Trzynadlowski, mogłem kontynuować i rozwijać rozmaite formy współpracy międzynarodowej, wciąż jako sekretarz tej międzynarodowej komisji. Po konferencji wrocławskiej w latach dziewięćdziesiątych, która była ostatnim obowiązkiem organizacyjnym wynikającym z naszej współpracy, kierownictwo Komisji Poetyki i Stylistyki Słowiańskiej przeszło w ręce slawistów czeskich (szczegóły na ten temat w książce Oblicza slawistyki pod redakcją Stanisława Gajdy).

W czasach przewodniczenia Pani Profesor wspomnianej komisji trzykrotnie miałem okazję towarzyszyć jej w podróżach. Tu trzeba przypomnieć, że po wypadku musiała ona przy chodzeniu korzystać z laski. Rzadko więc decydowała się na dalsze wyjazdy, kiedy trzeba było np. korzystać z pociagu. Ale tym razem całkiem dobrze zniosła podróże do Warszawy, bo tam w Pałacu Staszica odbywały się trzydniowe posiedzenia naszej konferencji slawistycznej w r. 1972, a rok później Warszawa była organizatorem wielkiego Kongresu Slawistów, gromadzącego slawistów z całego świata. Pani Profesor mieszkała wtedy w hotelu „Bristol”. Pamiętam, jak 
któregoś ranka, przyszedłszy do jej pokoju, zobaczyłem pościel z poduszkami przeniesione na podłogę. „W łóżku było mi zbyt duszno, więc zdecydowałam pościelić sobie na podłodze" - wyjaśniała. Podczas lipcowych dni, kiedy odbywał się kongres, rzeczywiście było nadzwyczaj upalnie, a Pani Profesor przydzielono pokój na najwyższym piętrze. Po mojej interwencji w recepcji przeniesiono jej lokum natychmiast na pierwsze piętro, gdzie funkcjonował jakiś pozór klimatyzacji.

W tymże „Bristolu” jadaliśmy też kolacje. Menu było na poziomie, ale i ceny także. Zatem Pani Profesor (nie wypada płacić kobiecie - uważała - gdy siedzi z mężczyzną) podawała mnie, chudemu adiunktowi, pod stolikiem swój portfel, abym to ja mógł regulować rachunki! Któregoś wieczoru, kiedy siadaliśmy do kolacji, pojawiła się w hotelowej restauracji trójka gości, którzy widząc Panią Profesor postanowili się do nas przysiasść. A byli to profesorowie Jerzy Kuryłowicz (18951978), Roman Jakobson (1896-1982) i jego żona Krystyna Pomorska (1928-1986)! Już nie pamiętam, co kelner podawał, co piliśmy i na jaki temat prowadzono rozmowy. Tylko pani Krystyna co pewien czas strofowała męża: „Roman, mów po polsku"! Bo Jakobson opowiadał rozmaite anegdoty posługując się w jednym zdaniu paroma słowiańskimi językami naraz. Nie muszę dodawać, że dla prowincjusza $z$ Łodzi ten wieczór musiał być wyjątkowy. Choć zastanawiałem się, czy wypada mi się śmiać z niektórych, ryzykownych obyczajowo anegdot, zwłaszcza Kuryłowicza, ale - jak się okazało - wśród językoznawców wolno więcej! Kuryłowicz, co wiem dzisiaj, bo wtedy Pani Profesor nie wspomniała ani pół słowem na ten temat, wybitny i sławny językoznawca, w okresie międzywojennym był profesorem Uniwersytetu Jana Kazimierza we Lwowie, a urodził się w Stanisławowie! Stąd ta przyjazna zażyłość okazywana sobie przy kolacji, co mnie wówczas nieco zastanawiało, bo nie znałem życiorysu profesora. A z Krystyną Pomorska jeszcze potem do jej śmierci utrzymywałem osobiste (udział w konferencji sztokholmskiej) i korespondencyjne kontakty. Wysyłałem jej do USA polskie nowości literackie, które ją szczególnie interesowały.

Podczas kongresu byłem też świadkiem spotkania Pani Profesor z Marią Renata Mayenowa pod arkadami Pałacu Staszica. Przywitanie było grzeczne, ale na rozmowę czasu nie stało. Pani Mayenowa popatrzyła na nas i rzekła: „Ty, Stefanio, jak zwykle otoczona mężczyznami!” Pani Profesor coś kwaśno odrzekła i tak poszliśmy dalej w różnych kierunkach - Mayenowa do pałacu, a my, bez jakichkolwiek komentarzy, do hotelu. Po latach obie panie profesor spotkały się zgodnie, acz symbolicznie, dzięki prof. Elżbiecie Feliksiak, doktorantce Skwarczyńskiej, która zamierzyła na uczelni w Białymstoku serię wydawnicza „Poetyka i Horyzonty Tradycji”, wydając tam obok siebie dwie ksiażki w r. 2006, właśnie wybór studiów Mayenowej zatytułowany Obecność i wznowienie sławnej monografii Skwarczyńskiej Teoria listu.

Nasza podróż z Panią Profesor do Tihany nad Balatonem przez Budapeszt też nie obyła się bez przygód. Zorganizowano tam w maju 1974 konferencję Komisji Poetyki i Stylistyki Słowiańskiej. Dział zagraniczny łódzkiej uczelni zadbał o bilety kolejowe, które wręczono nam przed wyjazdem. Pani Profesor otrzymała bilet w wagonie sypialnym, ja w kuszetce - wedle rangi, co oczywiste. Ale w pociagu okazało się, że bilet Pani Profesor wskazywał jej miejsce na górnym (!) łóżku. Na dole miała spać jakaś dystyngowana pasażerka, Węgierka, z którą porozumiewaliśmy się po 
francusku. Wyjściem w zaistniałej sytuacji była tylko zamiana: Węgierka na górze, a Pani Profesor na dole. Ale pani z Budapesztu nijak nie dała się przekonać do tego pomysłu. Co więc robić? Przed nami całonocna podróż, a Pani Profesor w żaden sposób nie wdrapie się na górę. Po dłuższej naradzie, polsko-francuskiej, to ja miałem spać na górze, a Pani Profesor na moim miejscu w przedziale kuszetkowym drugiej klasy! Ale był jeszcze jeden problem - obyczajowy! Więc najpierw ja się rozbierałem i skrobałem na górę, a dopiero potem Węgierka wracała $z$ korytarza i zajmowała swoje miejsce na dole. Rano zaś odwrotnie... Nie pamiętam, czy z wrażenia spałem tamtej nocy. Tak czy tak, spięty biegnę rano do wagonu z Panią Profesor $\mathrm{z}$ pytaniem: jak minęła noc? A Pani Profesor uśmiechnięta - jak się okazało - przegadała cały czas z sąsiadami z przedziału...

W Tihany było luksusowo i pięknie, bo oto konferencję zorganizowano w ośrodku partyjnym tuż nad Balatonem, w pięknych okolicznościach przyrody. Nieopodal głównego budynku stał pośród drzew kiosk, gdzie nam, uczestnikom konferencji, serwowano gratis wina. Jak pamiętam, pewien profesor, wybitny językoznawca i semantyk z Warszawy, przestał pod tym kioskiem większość pobytu na konferencji $z$ kielichem białego wina w ręku.

Ale i tu spotkała nas nieprzyjemna na poczatku sprawa. W Polsce otrzymaliśmy jakieś pieniężne vouchery do wymiany u organizatorów konferencji na forinty. Każdy podchodził do małego kantorka, gdzie młoda dziewczyna wymieniała nasze bony na węgierskie pieniądze. Zainteresowałem się już w pokoju, jakie pieniądze otrzymała Pani Profesor, bo wydało mi się, że coś za mało! Policzyliśmy i... rzeczywiście. Zaraz pobiegłem z interwencją do prof. Mihálya Pétera, węgierskiego szefa konferencji, i za chwile - ku podziwowi Pani Profesor - przyniosłem cały dodatkowy plik należnych jej forintów. Potem usłyszałem przypadkowo, jak Pani Profesor mówi do Teresy Cieślikowskiej (która też była $\mathrm{z}$ nami na konferencji), komentując całe wydarzenie z podziwem: „Bo pan Grześ jak kot - chodzi własnymi drogami”!

Bardziej dramatyczny charakter miała na początku nasza wspólna podróż na konferencję do enerdowskiego Lipska. Tam zgromadzenie slawistów organizował prof. Gerhard Dudek, nb. świetnie mówiący po polsku. Podróż z dworca Łódź-Chojny koleją 26 I 1977 tym razem minęła jak najlepiej, beż żadnych przygód. Bardzo wczesnym rankiem przybyliśmy do Lipska. I w pustej (oprócz nas nie było nikogo), ogromnej hali dworcowej (samolot mógłby lądować!) Pani Profesor, widocznie zmęczona, postanowiła się położyć na kamiennej posadzce, bo nigdzie nie było ani pół ławki, ani żadnego załomka muru, dosłownie nic! Najpierw sie przeraziłem, bo znikąd pomocy. Więc czekając, aż może pojawi się prof. Dudek, stałem dobrych kilka minut nad leżącą Panią Profesor, cały zdrętwiały z niemocy i od gonitwy myśli. Ale po niedługim czasie Pani Profesor - kiedy nieco odpoczęła - podniosła się przy mojej pomocy. Wtedy dopiero zauważyłem, jak w odległych drzwiach dworca pojawił się prof. Dudek, i odetchnąłem. A Pani Profesor, jakby nic się stało, przeszła kilkadziesiąt metrów do taksówki i tak dojechaliśmy do hotelu. Całe to wydarzenie, przecież dramatyczne, nie miało dalszych konsekwencji. Pani Profesor - przewodnicząca komisji - spełniła wszystkie swoje obowiązki bez zarzutu, kierowała obradami, zabierała głos w dyskusji i jak zawsze błyszczała pośród slawistycznej międzynarodówki. A każdego wieczoru, po trudach dnia, częstowała mnie kieliszkiem budafoku, którego butelkę zabrała $z$ Łodzi. 
W dobrym samopoczuciu i w niezłych humorach wracaliśmy więc do domu, towarzyszył nam do Wrocławia też prof. Jan Trzynadlowski, uczestnik lipskiej konferencji. Kiedy na granicy wkroczył celnik, zawiadomiliśmy go, ja i pan Jan, że nie wieziemy żadnych artykułów dziecięcych (wtedy obowiązywał ścisły zakaz wymyślony przez enerdowców). Gdy przekroczyliśmy granicę i zaczęliśmy z profesorem pokazywać sobie różne dziecięce ubranka i buciki, których nakupiliśmy (on dla wnuczków, ja dla syna Michasia), Pani Profesor popatrywała na nasze rozradowanie miny bez aprobaty, ale i bez komentarza.

Tu, aby wyjaśnić wszystkie zaszłości naszej lipskiej wizyty konferencyjnej, powinienem przywołać jeszcze jeden fakt. Pani Profesor podczas swoich bytności w katedrze, zwłaszcza pod koniec uniwersyteckich obowiązków, nierzadko przez kilkanaście minut odpoczywała w pozycji leżącej na ułożonych krzesłach w salce na trzecim piętrze naszej siedziby na Matejki. Ale potem po jakimś czasie wstawała i jakby nigdy nic kończyła tego dnia profesorskie i kierownicze obowiąki.

Jeszcze jeden obszar mojej współpracy z Panią Profesor wydaje mi się szczególnie istotny: obowiązi redakcyjno-organizacyjne związane z półrocznikiem „Zagadnienia Rodzajów Literackich”. Pani Profesor jako redaktor naczelna (przy współudziale profesorów Witolda Ostrowskiego i Jana Trzynadlowskiego) redagowała i wydawała, najpierw pod egidą Ossolineum, a potem Łódzkiego Towarzystwa Naukowego, to ważne, międzynarodowe, wielojęzyczne czasopismo naukowe od samych początków w 1958 r. aż do swojej śmierci w 1988 roku. Najpierw byłem gońcem, potem łącznikiem między redakcją (która całkowicie mieściła się w mieszkaniu prywatnym Pani Profesor przy ul. Narutowicza 79; część dużego biurka wydzielona została na potrzeby redakcji) a wydawcą (różne łódzkie siedziby), aż wreszcie, po śmierci Pani Profesor i wrocławianina Jana Trzynadlowskiego, ŁTN powołało mnie na stanowisko redaktora naczelnego, które sprawowałem nader sumiennie - jak myślę - przez więcej niż dziesięciolecie do 2010 roku. A też redakcję prowadziłem we własnym mieszkaniu!

Pismo funkcjonuje do dnia dzisiejszego, teraz pod kierownictwem prof. Jarosława Płuciennika. A ja zostałem uhonorowany w 2010 r. medalem za specjalne zasługi na rzecz edytora, czyli Łódzkiego Towarzystwa Naukowego. Pod swoją redakcją - przy współpracy kolegów z Instytutu Teorii Literatury, Teatru i Filmu UŁ - doprowadziłem też dwukrotnie (w „Universitasie” i - w znacznie rozszerzonej wersji - w PWN-ie) do publikacji nagradzanego i bardzo dobrze przyjętego Słownika rodzajów i gatunków literackich, o którego realizację Stefania Skwarczyńska zabiegała bezskutecznie jeszcze na początku lat pięćdziesiątych (o czym już pisałem) i dla którego realizacji przecież przed wielu, wielu laty, w r. 1958, powołano czasopismo „Zagadnienia Rodzajów Literackich”. Jak wspomniałem, w r. 2015 w Belgradzie słownik ukazał się w przekładzie na serbski! Można zatem obiektywnie rzec, że wraz $\mathrm{z}$ instytutowymi kolegami z Katedry Teorii Literatury zrealizowaliśmy najlepiej jak umieliśmy - korygujacc, uzupełniajac i dopełniając - to ambitne założenie naukowo-wydawnicze $z$ lat pięćdziesiątych.

A czasopismo - to niecodzienna sprawa - powstało na skutek wyroku sądowego! W okresie, gdy kształtowała się sprawa słownika gatunków literackich, jeden z jego ówczesnych współpracowników, doc. Stanisław Łukasik (1897-1962; były żołnierz legionista, walczył m.in. w obronie polskości Lwowa $\lfloor!\rangle$, habilitował się 
z romanistyki na Uniwersytecie Jagiellońskim w r. 1945), tak pilnie zabrał się do pracy, że wkrótce napisał kilkadziesiąt haseł. A tu sprawa wydania słownika upadła! Pan Łukasik uznał, że ŁTN nie dotrzymało umowy, więc podał sprawę do sądu! Po rozprawie zaś sąd stwierdził, że trzeba pilnemu autorowi, który wywiązał się z umowy, zapewnić publikację! Zatem, rada w radę, szefowie Towarzystwa postanowili zaczać wydawać czasopismo „Zagadnienia Rodzajów Literackich” pod redakcją Stefanii Skwarczyńskiej, w którym w pierwszej kolejności drukowały się - bardzo dobre zresztą - hasła pana Łukasika, który zmarł w r. 1962, ciesząc się zapewne swoimi publikacjami.

Pani Profesor była aktywna do końca życia. Wspierała nas w działaniach związanych z wydawaniem „Zagadnień Rodzajów Literackich”. Starała się jeszcze publikować. Kiedy przygotowywano we Wrocławiu księgę ku czci Trzynadlowskiego, postanowiła zaproponować publikację dużego fragmentu przygotowywanej przez siebie monografii poświęconej poetyckim dziejom motywów korony cierniowej i wawrzynu. Po kilkunastu dniach powiadomiono mnie z Ossolineum, że ten tekst nie będzie mógł być opublikowany, nie nadaje się bowiem do druku ze względu na liczne poprawki i niekonsekwencje. Okazało się - jak potem rzecz wyjaśniałem - że przez pomyłkę Pani Profesor wysłała szkicową wersję artykułu zamiast wersji w pełni zredagowanej. Ostateczny tekst, który odnaleźliśmy z Panią Profesor, bez przeszkód został skierowany do druku i uświetniał jubileusz 75-lecia wrocławskiego profesora w ofiarowanym mu tomie W kregu historii i teorii literatury (1987). To była ostatnia jej publikacja za życia. Ktoś niedawno mnie zapytał, czy to prawda, że wydawnictwo ossolińskie odrzuciło propozycję publikacji ostatniej książki Skwarczyńskiej ze względu na niski poziom. Tak oto tamto niedopatrzenie urosło w nieżyczliwej plotce do quasi-faktu, który się oto plącze w naszym życiu akademickim.

Wciąż pamiętam ostatni dzień bytności Pani Profesor we wrześniu 1973 w katedrze - już wtedy, od kilku miesięcy, w nowo powołanym, w jej miejsce, Instytucie Teorii Literatury, Teatru i Filmu, którego dyrektorem została właśnie mianowana. Siedzieliśmy wszyscy w jej gabinecie, markotni i cisi. Pani Profesor za biurkiem, na którym w dużym wazonie piętrzyły się kwiaty. Wzięła do ręki leżący tam tomik wierszy i poprosiła dr Grażynę Szymczyk, która była jej doktorantką, szczególnie zainteresowaną polska poezją współczesną, aby przeczytała wiersz Zbigniewa Herberta Tren Fortynbrasa. Grażyna - przejęta i wzruszona, jak my wszyscy - recytowała ten wiersz z drżącymi rękami. Milczeliśmy potem przez dłuższą chwilę, aż Pani Profesor, z uśmiechem dotykając bukietu, powiedziała coś na temat jego barwnej urody i przywróciła nas do rzeczywistości. Trzeba było myśleć już o nowym roku akademickim.

Pod koniec lat osiemdziesiątych, na kilka miesięcy przed śmiercią Pani Profesor, ukazał się szósty - i ostatni - wolumin jej ważnego projektu edytorskiego, czyli Teorii badań literackich za granica, zainicjowanego przez krakowskie Wydawnictwo Literackie jeszcze w 1965 roku! Przeszło 20 lat musiała czekać Pani Profesor, aby wreszcie wszystkie tomy postawić obok siebie na półce i wreszcie doprowadzić rzecz do końca, choć była merytorycznie i redakcyjnie przygotowana u samych początków. Do dziś nie wiem, kto o tym decydował i jakie były przyczyny tego wydawniczego rekordu. I ten tom też $-z$ dedykacją Pani Profesor - uświetnia w mojej domowej bibliotece półki z jej książkami (także opatrzone jej autografami, zaczynającymi się 
od słów „Panu magistrowi...”, a na koniec - w ostatnich książkach - „Drogiemu Panu... serdecznemu mojemu przyjacielowi”).

$N b$. mam - poczynając od lwowskiego debiutu - wszystkie kilkanaście książek opublikowanych przez Panią Profesor przed wojną i po wojnie. Oraz wiele dziesiątków tzw. nadbitek. Także dzięki córce Pani Profesor, Marii Olszewskiej, której wraz z prof. Kaszyńskim pomagaliśmy porządkować pozostawione w mieszkaniu matki archiwalia, wszelkie dokumenty związane z pracą uniwersytecką, bibliotekę, notatki i liczne maszynopisy. Zostały one przekazane sumiennie Działowi Dokumentacji Społecznej łódzkiej biblioteki uniwersyteckiej. My, ja i Kaszyński, mogliśmy wybrać sobie te książki, nadbitki i inne druki Pani Profesor, których nie mieliśmy, a które biblioteka uczelniana już posiadała. Na marginesie: znalazł się też wtedy nabywca dużego wojskowego księgozbioru pana pułkownika Skwarczyńskiego.

Jeden z profesorów ma do dziś do Pani Profesor ideową pretensję, dlaczego wydawała swoje książki w „Paxie”, wydawnictwie Bolesława Piaseckiego. Bo rzeczywiście niemal wszystkie książki Stefanii Skwarczyńskiej firmował „Pax”. Po pierwsze, mógłbym zapytać: a kto miał po wojnie wydawać te książki; które z państwowych oficyn odważyłyby się opublikować ksiażkę autorki sekowanej przez socjalistyczne władze, pozbawionej w latach pięćdziesiątych katedry i zagrożonej utrata pracy akademickiej?! Nie będę się wdawał w opis związków Pani Profesor z „Paxem”, bo nigdy tej sprawy nie badałem. Mogę powiedzieć, że chociaż była osobą wierząca, nigdy się z tym nie obnosiła ani nie próbowała komentować zachowań katedralnych niedowiarków, a i członków partii (bo było pod jej skrzydłami paru!). Skwarczyńska nigdy też nie manifestowała ani nie próbowała objaśniać nam swoich ideologicznych więzi z Bolesławem Piaseckim! Czterokrotnie otrzymała Nagrodę Naukową im. Włodzimierza Pietrzaka (patron nagrody zginął podczas powstania warszawskiego, był związany ze środowiskiem „Sztuki i Narodu”). Najpierw fundatorem tej nagrody było środowisko czasopisma „Dziś i Jutro”, z którym Pani Profesor współpracowała, potem Stowarzyszenie „Pax”, a następnie Stowarzyszenie „Civitas Christiana”. Skwarczyńska była też jurorką nagrody Pietrzaka oraz ogólnopolskiego konkursu poetyckiego ogłaszanego przez łódzki oddział „Paxu” („,ódzka Wiosna Poetycka”) w latach 1959-1975.

W roku 1985 we wstępie do tomu W orbicie literatury, teatru i kultury naukowej pisała:

[...] Instytutowi Wydawniczemu „Pax” zawdzięczam edycję dziesięciu moich książek. A jest to połowa mojego książkowego dorobku naukowego po II wojnie światowej [...], z tym że zasługa wydania tej drugiej połowy przypada aż trzem oficynom wydawniczym. Wobec tego stanu rzeczy jakże autorce nie pokłonić się ze szczególną wdzięcznością Instytutowi Wydawniczemu „Pax” w trzydziestolecie żywych wielorako i serdecznych z nim stosunków? Jakże mu nie podziękować, że wyciągnąwszy ongi do mnie rękę, brał pod uwagę, ze swego ideowego punktu widzenia, raczej moją postawę i poglądy niż charakter mojej specjalności naukowej [...]. A może Instytut dostrzegł w moich pracach jakżeż ważny z jego punktu widzenia aspekt historyczny [...] oraz moją wierność empirii jako bazie badawczej i jako podstawie do uogólnień, mniej lub bardziej zuniwersalizowanych. A może zauważył z pewnym zadowoleniem, iż mój wybór materiału literackiego do badawczych dociekań padał często na twórczość wielkich sztuką i wielkich duchem artystów. W obrębie literatury polskiej takich jak Mickiewicz, Słowacki, Krasiński, także Norwid i Kochanowski, a zwłaszcza ostatnio - Wyspiański. W obrębie literatury francuskiej takich jak Pascal, Hugo i wielu innych [...], w obrębie literatury niemieckiej na takich jak Schiller i Goethe.

„Pax” nie narzucał tematów swoim autorom, nie ograniczał ich swobody twór- 
czej, a publikacje, zwłaszcza te tłumaczone na polski były - na tle państwowych wydawców pod okiem cenzorów - cennym wzbogaceniem recepcji literatury światowej. A czy ważne książki Skwarczyńskiej, tworzone regularnie przez cały okres pracy akademickiej, miały pozostawać w rękopisach?! Próby współpracy z innymi wydawnictwami nie dawały dobrych rezultatów. Wspomniałem już, jak jej ważną 6-tomowa prace publikowało na raty Wydawnictwo Literackie przez 20 lat!

Na początku lat osiemdziesiatych, jeszcze za życia Pani Profesor, a z inicjatywy dr. Jacka Zaorskiego, polonisty-wykładowcy UŁ i jednocześnie dyrektora Wydawnictwa Łódzkiego, podjęliśmy się z dr Danuta Szajnert opracowania i przygotowania do druku reedycji trzech tomów Wstępu do nauki o literaturze, które wychodziły przed laty w „Paxie” (tomy 1-2 w r. 1953, a tom 3 w r. 1965). Należało uzupełnić przypisy, zrobić korekty całości, a w pierwszym tomie wyrzucić wszelkie wstawki o stanowisku marksistów, wyraźnie wymuszane na autorce. Te skreślenia były łatwe, ale też nie miały absolutnie żadnego wpływu na tok wykładu. Od razu było widać, że Pani Profesor dopisywała je „na życzenie”. Pierwsze dwa tomy przygotowaliśmy nawet dość szybko, pracując usilnie przez parę tygodni, trzeci tom $\mathrm{w}$ istocie rzeczy nie wymagał specjalnych korekt. Wszystkie nasze działania konsultowaliśmy oczywiście $z$ Panią Profesor, która w zasadzie - jak to się mawia - dała zielone światło dla naszych korekt i redakcyjnych decyzji. Dziś jednak nie bez wątpliwości zastanawiam się, czy był to dobry pomysł, aby „poprawiać historie”. Może dobrze się więc stało, dla wszystkich zainteresowanych, że okoliczności (brak pieniędzy i upadek wydawnictwa) zadecydowały ostatecznie, iż projekt nie doczekał się realizacji.

Nie będę tu rekonstruował albo interpretował światopoglądu Pani Profesor, bo też nigdy się $\mathrm{z}$ tymi sprawami nie obnosiła. A przecież $\mathrm{z}$ tak poharataną tragicznie przez ten ustrój biografia - własną i całej rodziny - mogła głęboko nienawidzić wszelkich odmian radzieckiego, stalinowskiego komunizmu. Musiała się zetknąć wtedy pośrednio w swoim kresowym życiu $\mathrm{z}$ najgorszymi, zbrodniczymi reżimami i ideologiami, które wywoływały wówczas dwa pogromy antysemickie we Lwowie (w czasie walk wyzwoleńczych w r. 1918 i w 1941, tuż po wkroczeniu Niemców), w innych kresowych miasteczkach i większych zbiorowiskach w latach 1918-1919 (Pińsk - 38 ofiar, Wilno - ponad 60 ofiar, Mińsk - 31 ofiar, Lida - 39 zabitych, Żytomierz - 58 zastrzelonych). Musiano także w domu starosty rozmawiać o bratobójczych walkach o Lwów między sąsiadami polskimi i ukraińskimi, potem o skrajnie antyhumanistycznych ideologiach rodzacego się hitleryzmu i komuniz$\mathrm{mu}$, o ofiarach na polskich i ukraińskich Kresach. Skwarczyńska nie ugięła się też faktycznie w latach realnego socjalizmu. Siedziała $z$ nami i ze studentami na znak solidarności przez większą część nocy podczas strajku okupacyjnego w łódzkiej bibliotece uniwersyteckiej w marcu 1968. Pomogła Zdzisławowi Jaskule, młodemu poloniście i poecie, relegowanemu z UŁ, ukończyć studia na KUL-u. Solidaryzowała się również z uczonymi, którzy zwalniani decydowali się na emigrację. Wspierała ich opiniami i pisemnymi rekomendacjami. Pamiętam, jak Panią Profesor odwiedził Samuel Sandler, który emigrował z Polski w 1969 roku.

W lipcu 1946 jako jedna $z$ bardzo nielicznych polskich inteligentek bardzo dramatycznie komentowała w „Tygodniku Powszechnym” (1946, nr 3) pogrom kielecki, podczas którego zamordowano 41 mieszkańców pochodzenia żydowskiego: 
Mord kielecki wstrząsnął nami do dna, tym bardziej - powiedzmy sobie szczerze - że nas zaskoczył. Zaskoczył tym, że to w ogóle mogło się stać. Bo ostatecznie każdy wie, że nawet w najwyżej stojącym społeczeństwie mogą się trafić głupcy, szaleńcy czy zbrodniarze, ale jak się ustosunkować do faktu, że na ludzi spokojnych, straszliwie dopiero co skrzywdzonych przez czasy, któreśmy przeszli - rzuca się z rewolwerami i rurami od kaloryferów rozwścieczony tłum. Że rzecz rozgrywa się nie w jakimś kwadransie podniecenia, ale przez sześć godzin, a więc w czasie wystarczającym do opamiętania. [...] Żydzi w Polsce są i nadal będą pod opieką naszej chrześcijańskiej i polskiej kultury. Wara od nich obcym, złym siłom, wara naciskowi głupoty i zbrodni.

W oskarżeniu tym nie wspominała swoich obserwacji i doświadczeń wyniesionych $\mathrm{z}$ uniwersyteckich lat lwowskich. A kalendarium Dwudziestolecia międzywojennego tego miasta to nieustanne pasmo utarczek, napaści i sytuacji pogromowych. Dosłownie - nie było we Lwowie tygodnia (zwłaszcza w latach trzydziestych) bez masowych antysemickich demonstracji studentów $z$ organizacji endecko-korporacyjnych i narodowych, bez bojówkarskich wystapień z żądaniami wprowadzenia na tamtejszych uczelniach rygorów numerus clausus, bez wymuszania getta ławkowego lub całkowitego zamknięcia uczelni wyższych dla Żydów (numerus nullus). Te antysemickie demonstracje przeradzały się nader często w pałkarskie bójki po całym mieście, w napaści na sklepy żydowskie i w inne sytuacje pogromowe, kończące się niekiedy ofiarami śmiertelnymi. Owszem, przeciw nim reagowały po wielekroć władze uczelniane, także rektorzy, zamykając nieraz tymczasowo uniwersytet, interweniowała przeciw antyżydowskim burdom również policja, ale w istocie rzeczy nie na wiele się to zdało. Takie sytuacje trwały aż po lata trzydzieste.

Kulminacja antyżydowskich akcji nastapiła w UJK w latach 1937-1939. Kiedy rektor Kulczyński jako jedyny w Polsce odważnie przeciwstawił się wprowadzeniu oficjalnie getta ławkowego, rozwścieczeni studenci podjęli protesty na niespotykaną wcześniej skalę.

- rekonstruuje te wydarzenia wspominany już Mariusz Chrostek w monografii Złote lata polonistyki lwowskiej (1919-1939):

Nasiliły się bójki, burdy, walki w murach uczelni i na ulicach, przeprowadzanie tzw. dni bez Żydów, czyli uniemożliwienie im wstępu na teren uniwersytetu. Wybijano szyby i demolowano żydowskie lokale, dochodziło nawet do pobić personelu uczelni [...]. Pod naciskiem i groźbą jeszcze większej przemocy senaty wszystkich trzech uczelni wprowadziły 7 stycznia 1938 roku getto ławkowe. Dla młodzieży antysemickiej ten krok okazał się niewystarczający. Powrócili do zasady numerus nullus, która już od stycznia zaczęli uskuteczniać siłą, wpadając dużymi grupami na wykłady, bijąc w obecności profesorów żydowskich studentów i przemocą usuwając ich z sal.

Niedawno zmarła Zenona Macużanka, działaczka zetempowska, studentka filologii, która wraz ze swoimi młodymi poplecznikami w czerwonych chustach chciała wyrzucić prof. Stefanię Skwarczyńską z Uniwersytetu Łódzkiego na początku lat pięćdziesiątych. Na szczęście ówczesny rektor UŁ, prof. Jan Szczepański (1913-2004), odważnie do tego nie dopuścił. Katedra została wprawdzie zawieszona, ale Profesor pozostała w składzie pracowników UŁ. Po latach podobno pani Zenona łasiła się $\mathrm{z}$ przeprosinami $\mathrm{i}$ - jak znam Panią Profesor - zapewne uzyskała przebaczenie, „naprawiała” więc swoje błędy (jakby można je było naprawić!) peanami i okładkami z portretem Pani Profesor w „Nowych Książkach” (Macużanka była ich redaktorem naczelnym).

Pani Profesor odchodziła na emeryturę w r. 1973 (w tym roku kończyła 70 lat). Nie wiem, czy obowiazywały wtedy na ten temat rygorystyczne przepisy i czy mogła 
jeszcze pracować. Nie pamiętam też, czy o tym szczegółowiej rozmawialiśmy. Ale już kilka miesięcy przed ostatnim rokiem akademickim, kiedy w miejsce katedry został powołany Instytut Teorii Literatury, Teatru i Filmu z trzema katedrami (o co Pani Profesor pod koniec swojego urzędowania usilnie zabiegała), mówiło się, że jej obowiązki dyrektora instytutu przejmie prof. Lewicki. Pojawiło się też przy okazji nowe stanowisko do objęcia - zastępca dyrektora. I prof. Lewicki już ze mną na ten temat rozmawiał. Pani Profesor chciała jednak, abym został przy literaturoznawstwie, obawiała się może, że pełniąc nową funkcję zmienię specjalność naukową. To według niej nie mogło się zdarzyć. Ale sytuacja - by tak rzec - rozwiązała się sama. Bo oto wyraźniej zarysował się projekt mojego wyjazdu do Francji, w którego ramach miałem objąć na którymś $z$ tamtejszych uniwersytetów obowiązki lektora i wykładowcy języka polskiego. $Z$ takiego trzyletniego pobytu na uczelni w Lyonie wrócił właśnie dr Świontek i bardzo przekonująco namawiał mnie na podobny wyjazd. Pani prof. Skwarczyńska - jak się zorientowałem - była dosyć niechętna pomysłom takich podróży, zwłaszcza dłuższych, bo uważała, że to opóźni przygotowanie habilitacji i moją dalszą przyszłość naukową. A bez jej poparcia wyjazd był trudny do zrealizowania. Jednakże w obliczu zmian personalnych, które rysowały się w chwili, gdy przechodziła na emeryturę, uznała, że lepiej będzie, abym wyjechał, niż abym pełnił funkcję zastępcy dyrektora.

Gdy 30 IX 1973 Pani Profesor przeszła na emeryturę, jej obowiąki przejął Lewicki i ostatecznie to Sławek Świontek podjął się funkcji zastępcy dyrektora, a ja w listopadzie 1974 wyjechałem z błogosławieństwem Pani Profesor na lektorat do normandzkiego Caen, na tamtejszy uniwersytet. Pisywaliśmy potem do siebie przez całe miesiące uprzejmie i serdecznie. Pani Profesor, sama kiedyś nauczyciel akademicki romanistyki, wciąż była wielce zainteresowana tym, co oglądałem, co we Francji czytałem $\mathrm{z}$ kręgu awangard literackich XX wieku, w którym literatura francuska odegrała tak istotną rolę. To tam wtedy we Francji rodził się projekt rozprawy habilitacyjnej na ten temat. Pani Profesor akceptowała ów pomysł (co i raz musiałem składać sprawozdanie $z$ postępów nad książka) i po latach była jednym $z$ recenzentów mojej habilitacji w 1986 r. w Uniwersytecie Łódzkim wraz profesorami Januszem Sławińskim, Stanisławem Jaworskim i Aliną Kowalczykową. Wymogła te obowiązki recenzyjne na powołanej przez Radę Wydziału komisji habilitacyjnej, bo w przepisach mowa była o warunku trzech recenzji, a poza tym jako recenzent mojego doktoratu raczej już nie powinna recenzować habilitacji. Ale mimo choroby i złego samopoczucia bardzo chciała wziąć udział w moim kolokwium. I tak też się stało. Moja żona organizowała logistykę przejazdu Pani Profesor na uniwersytet i z powrotem.

Tuż przed odejściem na emeryturę Pani Profesor porządkowała sprawy organizacyjne i naukowe katedry. Ogłosiła olbrzymie skontrum wszelkich spraw, od biblioteki zaczynając, a na sprawach administracyjnych kończąc. Uczestniczyłem oczywiście w tym kontrolnym spisie książek, mebli i przyborów biurowych, kiedy trzeba było wszystko policzyć i ustalić sposób oraz miejsce składowania. Żmudna to była praca i Pani Profesor, dostrzegajac moje znużenie, a i pewnie brak entuzjazmu, oceniła: „Niechaj się pan, panie Grzesiu, nie ociaga, przecież wszystko to kiedyś pan po mnie przejmie!” "Tak - stwierdziłem, niezbyt się nad tym zastanawiając - może za 20 lat...” Obyło się bez komentarza, a ja rzeczywiście równo po 20 latach objąłem, na więcej niż 10-lecie, kierownictwo instytutu, który przemia- 
nowaliśmy później na Instytut Kultury Współczesnej z siedzibą w pięknie odrestaurowanym i przydzielonym nam przez ówczesnego rektora, prof. Wiesława Pusia, Pałacu Biedermanna.

Dobrze się stało, że w którymś momencie - choć, moim zdaniem, było to znacznie za późno - łódzka Wytwórnia Filmów Oświatowych i Programów Edukacyjnych zdecydowała się przygotować film dokumentujący osobę i dokonania Pani Profesor. Choć byłem konsultantem jego twórcy, Zygmunta Skoniecznego (czego ślad pozostał w czołówce), który tuż przed nieodległa śmiercią Pani Profesor zrealizował obraz Stefania Skwarczyńska - szkic do portretu uczonej, nie mogę tego filmu dobrze ocenić. W swoim ciasnym mieszkaniu, wypełnionym książkami i dokumentami wieloletniej pracy, Pani Profesor siedząc przy biurku, opowiada o sobie i swojej pracy. Najbardziej wzruszajacy moment filmu to wspomnienie jej młodszej, wielce utalentowanej córki Joanny (1935-1948), która wraz z innymi harcerkami zginęła 18 VII 1948 w katastrofie na jeziorze Gardno. Pani Profesor czyta przed kamera poruszający tren, napisany w głębokim żalu po utracie dziecka.

Jeszcze raz oddam głos Kazimierzowi Kutzowi, przebywającemu wtedy nieopodal Łeby, w pobliżu jeziora Gardno, na którym podczas nagłej burzy z piorunami rozegrała się ta tragedia. Gdy Pani Profesor po wakacjach przyszła na swój pierwszy wykład, Kutz zobaczył ją „siwiuteńką,, ,jej twarz ściągnięta była grymasem bólu, w oczach tliło się cierpienie".

Osiwiała w jedną noc, dopadła ją przedwczesna starość, ale pod tą tragiczną przemianą prześwitywała wielka uroda. Musiała być piękną istotą z wołyńskich Kresów, ze starego rodu, bo takie się tam rodziły. Działa na mnie hipnotycznie i przez to, jak znosiła swoją tragedię. Moje utajone [...] stendhalowskie stygmaty karmiły się wtedy tą genialną panią.

W gabinecie Pani Profesor przez całe lata stał okragły stolik z fotografiami i drobiazgami Joanny, taki komemoracyjny ołtarzyk, kreujaccy symbol jej istnienia oraz stałej obecności w pamięci bliskich. A ja dopiero po latach poznałem początki - można rzec - kariery teatralnej Joanny (Janusi) w tajnych przedstawieniach lwowskiego teatru działającego podczas wojny pod egidą Bronisława Dąbrowskiego. Dziewczynka zagrała Lilusię w sztuce Ich czworo Gabrieli Zapolskiej i Isię w Weselu Stanisława Wyspiańskiego. Po „premierach” na strychu probostwa kościółka pw. św. Zofii widzowie obejrzeli jeszcze kilka spektakli.

A Joannę w teatrze widzowie zobaczyli znów już po wojnie (też w roli Lilusi) w Ich czworo w Łodzi w r. 1946, kiedy Teatr Kameralny wystawiał Zapolską. Do dzisiaj jej mogiła, pośród innych grobów harcerskich koleżanek na Starym Cmentarzu w Łodzi, jest stałym miejscem modlitw i smutnych adoracji odwiedzających.

Skonieczny zrobił zbyt krótki film, bez szkicowego scenariusza, nazbyt zdawkowy, aby objaśnić ogromny dorobek Uczonej i dramatyczne koleje życia jej bliskich i jej samej. Dobrze jednak, że taki film istnieje, można w nim bowiem zobaczyć wielką postać polskiej humanistyki. Do rozlicznych jej zaszczytów dodajmy jeszcze, że w r. 1981 Uniwersytet Łódzki nadał jej - absolwentce i doktorowi Uniwersytetu Jana Kazimierza we Lwowie - tytuł doktora honoris causa. Nie powtarzam już - za biogramami, które można znaleźć w Wikipedii, Polskim słowniku biograficznym, Britannice, Encyklopedii PWN itd. - informacji o licznych nagrodach (ministerialnych, miejskich i uniwersyteckich), o tytułach, wyróżnieniach, medalach i wyrazach uznania. 
Myślę, że z zamiarem realizacji filmu o Skwarczyńskiej nosił się i Grzegorz Królikiewicz. Poznałem go jeszcze w czasach studenckich - jego i moich. Trochę też z nim współpracowałem przy jego pierwszych próbach studencko-teatralnych, a także kiedy jako pracownik Telewizji Polskiej i szef Teatru Faktu przygotowywał serial o charakterze sagi rodzinnej, $z$ fabuła rozpięta między okresem rozbiorów a 1918 rokiem. Ponadto, już jako dyplomowany i znany reżyser filmowy, w połowie lat siedemdziesiątych (za mojej wicedyrektury i z mojej inicjatywy) przez semestr prowadził $\mathrm{u}$ nas $\mathrm{w}$ katedrze zajęcia $\mathrm{z}$ analizy dzieła filmowego, które cieszyły się ogromnym zainteresowaniem. To wtedy powstał i zaczął być realizowany projekt Królikiewicza tzw. złotej serii analiz dzieł filmowych (ukazało się kilkanaście tomów).

Zajęcia $z$ analizy przez kilka lat odbywały się potem w szkole filmowej; Uniwersytet Łódzki ze swoimi rygorami dydaktycznymi nie potrafił zaakceptować ich niekonwencjonalnego trybu tych zajęć. W roku 1988 przygotował Królikiewicz film „dokumentalny” Wiesz, jak jest, który miał ukazywać sylwetkę i dokonania prof. Lewickiego. Właściwie był to jednak zespół etiud-ćwiczeń realizacyjnych bez widocznego planu i scenariusza, w którym fantom Lewickiego (Profesor już wtedy nie żył) jest tylko pretekstem do zarysowania paru niejasnych intencji i montażowych eksperymentów. Może więc dobrze, że film o Skwarczyńskiej nie powstał. Natomiast Królikiewicz jako szef zespołu „Aneks” zwracał się do Pani Profesor z prośbą o analizę - z jej punktu widzenia - scenariusza do filmu będącego adaptacją powieści Stefana Żeromskiego Promień. Czytając tę analizę, mam wątpliwości, czy w jakikolwiek istotny sposób wpłynęła ona na kształt filmu, wyreżyserowanego ostatecznie przez Krzysztofa Sowińskiego w 1982 roku. Nb. Skwarczyńska była też konsultantką filmu o Jerzym Zawieyskim. A Królikiewicz nie odważył się - jak sądzę - robić filmu o niej samej.

Instytut - po latach jakby akcentując „eksperyment łódzki”, wiążąc badawczo (wedle idei Szefowej) filmoznawstwo i teatrologię z nauką o literaturze - występował jeszcze $z$ sukcesem do władz uniwersytetu o tytuły doktorów honoris causa dla Kazimierza Dejmka, Andrzeja Wajdy, Janusza Sławińskiego, zaznaczając swoje badawcze i dydaktyczne specjalności, a także dla Amosa Oza, wybitnego pisarza żydowskiego z Izraela, niejako podkreślając jego związki z Łodzią - kibucowymi rodzicami-opiekunami młodego Amosa byli bowiem Żydzi o łódzkich genealogiach.

Jak wspomniałem, Pani Profesor otrzymała w 1945 r. swoje pierwsze skromne lokum w Łodzi przy ul. Julianowskiej 22, dopiero w październiku 1964 przeniosła się do trzypokojowego mieszkania nr $18 \mathrm{z}$ maleńką kuchnią i łazienką, na pierwszym piętrze w bloku przy ul. Narutowicza 79, wybudowanego dla pracowników UŁ. Tam pracowała i żyła wraz z mężem i Wiktunią, która była nianią obu córek (jeszcze z czasów Dąbrówki!) na prawach członka rodziny, do ostatnich swoich dni. Pod nowym adresem każdy $z$ domowników miał własny pokój. W największym bytowała Pani Profesor; był on miejscem pracy z dużym biurkiem, regałami, ale także sypialnią ze stylowym łóżkiem oraz salonikiem $z$ fotelem i okrąłym stolikiem, gdzie przyjmowała gości. Było ciasno, lecz ze względu na niektóre, zapewne lwowskie meble, stylową komódkę, takiż zegar, wiszącą szafkę, stolik z pamiątkami po młodszej córce (o czym wspominałem), kobierzec nad łóżkiem i duży, wygodny fotel Pani Profesor - mieszkanie to miało charakter nobliwy i uroczysty. Na dużym biurku mnóstwo teczek, aktualnych dokumentów i listów, komplet „Zagadnień Rodzajów 
Literackich", wysłużona maszyna do pisania, którą trzeba było wspomagać licznymi korektami. Wszędzie dziesiątki zdjęć rodzinnych z różnych okresów, na honorowym miejscu zaś pośród książek portret Juliusza Kleinera. Na ścianach kilka olejnych portretów rodzinnych z przeszłości. Mieszkanie często było zadymione, bo Pani Profesor rzuciła palenie dość późno. Swój pokoik z wysokim łóżkiem miała niania - staruszeczka Wiktunia, a u pana pułkownika ważnym meblem były, oprócz łóżka, biurko z regałami obok, wypełnionymi książkami o tematyce historyczno-wojskowej. Wielokrotnie bywałem w tym mieszkaniu (,Wiktuniu, proszę kawę dla pana doktora!" - wołała Pani Profesor), zwłaszcza po swoim doktoracie i później podczas naszych prac w Komisji Poetyki Komitetu Slawistów i obowiązków redakcyjnych związanych z „Zagadnieniami Rodzajów Literackich”. Przy kawie lub herbacie i jakimś ciasteczku odbywały się też konsultacje doktorskie, habilitacyjne i wszelkie inne spotkania. Tam Pani Profesor przyjmowała gości z Polski i gości zagranicznych z całego świata. Tam również byłem świadkiem śmierci Wiktuni, któregoś mroźnego, śnieżnego lutowego popołudnia 1981, kiedy podczas wizyty wezwany do niani pilnie doktor pogotowia stwierdził jej zgon. W tych trudnych chwilach, także dla mnie (córka Maria przebywała wtedy służbowo w Warszawie), pomógł nam ktoś z zaprzyjaźnionej z Panią Profesor rodziny Kononowiczów.

Na jednej ze ścian pokoju Pani Profesor wisiał w złotawej, ale skromnej ramie średnich rozmiarów portret siedzącej bokiem postaci kobiecej (w planie amerykańskim - aby posłużyć się terminem z poetyki obrazu filmowego) ze złożonymi na udach rękami, w niebieskiej luźnej sukni. Kobieta o delikatnym profilu i krótkich rudawociemnych włosach mogła mieć ze 30 lat. Nie śmiałem rozpytywać, kto to. Potem się okazało, kiedy już byłem u Pani Profesor nieco - by tak rzec - zadomowiony i bardziej odważny w rozmowach, że ten pastel przedstawia właśnie samą Panią Profesor z lat trzydziestych. Dziś już wiem dokładnie, że narysował go Bolesław Kuźmiński (1880-1976), malarz, pedagog i wojskowy (w okresie międzywojennym dosłużył się stopnia majora wojska polskiego i - jak można przypuszczać był przyjacielem podpułkownika Tadeusza, czyli męża Pani Profesor).

Po śmierci Pani Profesor córka - pani Maria Olszewska - przekazała ten portret mnie. Dałem go do odkurzenia i odświeżenia i poprosiłem, aby zawieszono go w instytucie, w moim dyrektorskim gabinecie w Pałacu Biedermanna. Tak więc była obecna Pani Profesor w tym gabinecie przez moje ostatnie 15 lat na Uniwersytecie Łódzkim. Już na emeryturze, podczas jakiejś miłej dla mnie uroczystości w siedzibie Łódzkiego Towarzystwa Naukowego, postanowiłem przekazać ten portret ówczesnemu prezesowi ŁTN-u, czyli prof. Stanisławowi Liszewskiemu (1940-2016). Powiesił go był zaraz w swoim gabinecie. Teraz zmienił się prezes, a Pani Profesor, tak wielce zasłużona dla nauki w Łodzi, dla jej rozmaitych instytucji, jeszcze przez drugą wojną, także potem dla ŁTN-u, który współtworzyła, jest wciąż zainteresowana - symbolicznie, na portrecie - życiem naukowym naszego miasta.

O starszej córce Pani Profesor, Marii Joannie, po mężu Olszewskiej (1929-2011), myślałem nawet ostatnio podczas krótkiego pobytu turystycznego w Stanisławowie, bo tu właśnie, się urodziła. Teraz to Ukraina i Iwano-Frankiwsk, chciałoby się dodać niepolitycznie - niestety! W okresie międzywojennym Stanisławów był drugim obok Lwowa ważnym centrum kultury Kresów. Nazywano go „małym Lwowem”! Miasto Franciszka Karpińskiego, Jana Lama, Stanisława Vincenza, Ireneusza Ire- 
dyńskiego, Tomasza Weissa, Stanisława Frybesa i dzisiejszych znakomitości - Anny Seniuk i Feliksa Falka. Ale i podobno - prototypu pani Dulskiej!

Tu działała amatorska opera. I oczywiście od końca XIX w. stały teatr z ambitnym repertuarem, w którym zdażyła wystapić Helena Modrzejewska. Przy ładnej, słonecznej pogodzie chodziliśmy z żona po zadbanym, odrestaurowanym mądrze mieście, gdzie nie rzucają się w oczy sowieckie pomysły urbanizacyjne i gdzie pachnie zewsząd Polską - przynajmniej tak się nam wydawało. Miasto jest przytulne i kolorowe. Stoi nawet, w nieco zmienionej architekturze, synagoga im. Berka Joselewicza (niestety ze sklepem spożywczym w środku!), stoi pomnik Adama Mickiewicza na placu jego imienia, także kościół, w którym - według Henryka Sienkiewicza - odbywał się pogrzeb pułkownika Michała Wołodyjowskiego, czyli katedra rzymskokatolicka pw. Najświętszej Marii Panny. Stoi odnowiona wieża międzywojennego stowarzyszenia „Sokół” i modernistyczny ratusz. Także, jak na pocztówce z epoki, pasaż Gartenbergów!

Ale gdzie teatr, do którego chadzali Skwarczyńscy?! Szukaliśmy długo, aż para starych, zapewne stanisławowskich polonusów objaśniła nam, że trudno go znaleźć, bo to teraz budynek filharmonii, ale przebudowy pozwalają dostrzec jego XIX-wieczny kształt (najpierw im. Aleksandra Fredry) i międzywojenny (im. Stanisława Moniuszki, po drugiej wojnie przebudowa). Więc to tutaj, w wielonarodowościowym Stanisławowie, dwukrotnie w swoim życiorysie, młodziutka Stefania, znalazła się za mężem, Tadeuszem, kapitanem artylerii konnej, który tu właśnie wraz ze swoja jednostką stacjonował (od października 1921). Wcześniej młodzi zawarli ślub w Sanoku 5 VIII 1922 (we wrześniu tego roku zmarł, w wieku 65 lat, ojciec Stefanii, Mieczysław). Jak się wtedy mówiło, te zaślubiny połączyły „dwa wielkie kresowe rody”. Po 50 latach, dramatycznych przecież i nie wolnych od wydarzeń prawdziwie tragicznych, obchodzili w Łodzi, w rodzinnej atmosferze, złote gody w swojej parafii w kościele św. Teresy przy ul. Kopcińskiego.

Tematyka konfesyjna, wiary i Boga, pojawia się wyraźniej w - jak go nazywam notatniku kazachstańskim (fragmenty opublikowane przeze mnie, jak wspominałem wcześniej, w „Verte”, dodatku do „Gazety Wyborczej”), wypełnionym po części wypisami z Myśli Blaise'a Pascala (po drugiej wojnie ukazał się ten tom po polsku w „Paxie” w 1952 r. w przekładzie Tadeusza Boya-Żeleńskiego, ze wstępem Pani Profesor), a po części próbami dziennika, $z$ którego wynika przekonanie, że wiara pozwalała przetrwać najtrudniejsze momenty życia.

W Stanisławowie młoda Stefania, pełna pomysłów i idei, zafascynowana teatrem zaczęła pisać recenzje teatralne, felietony, analizy literackie dla młodzieży i dowcipne artykuły w „Kurierze Stanisławowskim” (wychodził od r. 1890). Napisała ponad 200 artykułów, parodii literatury polskiej i tekstów publicystycznych, którym dziś nadalibyśmy miano feministycznych (autorka poruszała problemy emancypacji kobiet kresowych; zredagowała specjalny numer tygodnika „Ziemia Stanisławowska", zapełniony wyłącznie tekstami kobiet o kobietach województwa stanisławowskiego). Pisywała też felietony o znanych postaciach literatury i sztuki europejskiej. Nie stroniła przy tym od dydaktyki. Te cechy wymienia ukraińska badaczka publicystycznej działalności Pani Profesor - dr Olga Ciwkacz z Uniwersytetu Przykarpackiego im. Wasyla Stefanyka w Iwano-Frankiwsku, edytorka niełatwo dostępnych recenzji, artykułów i felietonów Skwarczyńskiej. 
Gdzieś ktoś po latach krytykował te jej recenzje teatralne za dziennikarska prostotę, nie pamiętając chyba, że „Kurier” był pismem codziennym i popularnym, i raczej upowszechniał kulturę teatralną, niż interpretował ją z perspektywy teatrologicznej (na to przyszedł przecież czas w dojrzałym pisarstwie Pani Profesor!). Myślę, że nieodległe od prawdy byłoby stwierdzenie, iż właśnie w Stanisławowie młoda Stefania rozpoznawała teatr, jego estetykę i historię, tu - by tak rzec - uczyła się teatru, który po latach stał się jej naukową pasją, źródłem koncepcji teoretyczno-estetycznych nazwanych potem „teatralna teoria dramatu”. Teorię tee wyznawali Kazimierz Dejmek oraz - szczególnie - Adam Hanuszkiewicz, przyjaciel Pani Profesor i adorator jej osoby.

W Stanisławowie Skwarczyńska uczyła również języka polskiego i literatury (w liceum i gimnazjum sióstr urszulanek) i jezzyka francuskiego w Gimnazjum im. Elizy Orzeszkowej. I tu właśnie urodziła się 21 IV 1929 Maria Joanna. W Łodzi mieszka teraz jej córka - Joanna Olszewska, psycholog po studiach na UŁ, wnuczka Ewa i jej syn.

Z pobytu na Ukrainie przywiozłem też stare zdjęcie Kamionki Strumiłowej (w latach 1772-1918 miasto powiatowe Królestwa Galicji i Lodomerii), nostalgiczne i wzruszające, z niskimi domami, jakby za mgła, pustą ulicą i sylwetką wież kościelnych neogotyckiej świątyni Wniebowzięcia Najświętszej Marii Panny... Tam był starostą Mieczysław Strzelbicki, ojciec Stefanii, tam było też ich rodzinne gospodarstwo. W roku 1908 rodzina przeniosła się do Dąbrówki Polskiej pod Sanokiem, a pan Mieczysław - głowa rodziny - znów pełnił urząd starosty tym razem w c.k. Nowym Sączu, aby po przejściu na emeryturę w 1918 r. z całą rodziną osiąść w rodzinnym majątku w Dąbrówce.

Pogrzeb Stefanii Skwarczyńskiej w dniu 3 V 1988 na Starym Cmentarzu w Łodzi zgromadził całe miasto, a i wiele osób ze środowisk uniwersyteckich Polski. Odbył się w tym samym dniu, w którym po wojnie, w r. 1945, przybyła do Łodzi $z$ rodzina. Były przemówienia pod sztandarem Uniwersytetu Łódzkiego i wystapienia, także m.in. ks. prof. Bohdana Bejzego, biskupa wikariusza generalnego diecezji łódzkiej. Ale najwspanialsze i najbardziej wzruszające pożegnanie wygłosił prof. Jan Trzynadlowski, wychowanek Pani Profesor i kontynuator jej działalności na wielu akademickich polach. Ksiądz biskup $\mathrm{z}$ retoryczną zazdrością popatrywał i słuchał Trzynadlowskiego, który rzeczywiście - jak pamiętam - w każdej sytuacji, mniej lub bardziej uroczystej, okazywał wybitny talent oratorski. Tak było i na pogrzebie Stefanii Skwarczyńskiej, gdzie z nieukrywanym wzruszeniem słuchaliśmy jego słów.

Pani Profesor została pochowana obok męża, podpułkownika Tadeusza Skwarczyńskiego (zmarł w r. 1978), w istniejącym już grobie. Niedaleko kwatery ze zbiorową mogiłą harcerek tragicznie zmarłych podczas katastrofy na jeziorze Gardno, a więc również z mogiłą młodszej córki Pani Profesor, czyli Joanny (Janusi). Na tym samym cmentarzu, w innej jego części, jest też wspólny grób matki Tadeusza, Marii Skwarczyńskiej (Babci Niny; 1873-1963), a także prof. Marii Skwarczyńskiej-Olszewskiej (zm. 2011), i grób niani, przywoływanej już Wiktuni, czyli Wiktorii Borczyk (zm. 1981), którą pamiętam serdecznie ze wszystkich wizyt u Pani Profesor, zawsze życzliwie uśmiechniętej, kiedy podawała mi filiżankę herbaty $\mathrm{z}$ jakimiś tartinkami. 
Napisałem przed laty do księgi Łódzkiego Towarzystwa Naukowego (Pani Profesor była jego współzałożycielem w r. 1946) o roli nauczycieli w tworzeniu dziedzictwa kulturowego Łodzi niewielki artykuł O szkole naukowej Stefanii Skwarczyńskiej. Dzisiaj widzę, przypominając sobie jego treść, że był on nader zdawkowy, że więcej w nim było podziwu dla ogromu dzieła Uczonej niż argumentów potwierdzajacych tytułowy zamysł. Cokolwiek by na ten temat powiedzieć, trzeba przecież przyznać, że jej wykłady, książki, dyskusje podczas seminariów i konferencji nadały nam wszystkim, którzy mogą nazywać się jej uczniami i naukowymi wychowankami, umiejętności badawcze i wiedzę, pożytkowaną następnie przez nas samych i przekazywaną naszym wychowankom, wypromowanym przez nas magistrom, doktorom, potem profesorom w niejednej polskiej uczelni.

Pani Profesor opublikowała przed wojna we Lwowie cztery ksiazżki: Ewolucja obrazów u Słowackiego (1925; doktorat), Szkice z zakresu teorii literatury (1932; tu: O pojęcie literatury stosowanej, Istota improwizacji i jej stanowisko $w$ literaturze, Próba teorii rozmowy, Wartość treściowa kolorów), Rozwój wątków i obrazów w twórczości Mickiewicza (1934) i Teoria listu (1937).

Tuż po drugiej wojnie ukazały się kolejne publikacje: $Z$ teorii literatury. Cztery rozprawy (1947; tu: Przemilczenie jako element strukturalny dzieła literackiego, Geneza i rozwój rodzajów literackich, Struktura świata poetyckiego, Epos a powieść 〈essai〉), Systematyka głównych kierunków w badaniach literackich (t. 1; tom następny się nie ukazał), Studia i szkice literackie (t. 1-3, 1953; tu 16 studiów publikowanych wcześniej w czasopismach naukowych i księgach pamiątkowych Kleinera i Pigonia). W roku 1954 wyszły dwa tomy Wstępu do nauki o literaturze.

Po przywróceniu działalności Katedry Teorii Literatury na Uniwersytecie Łódzkim zaczęły się ukazywać: Mickiewiczowskie „powinowactwa z wyboru” (1957), Leona Schillera trzy opracowania „Nie-Boskiej komedii” $w$ dziejach jej inscenizacji $w$ Polsce (1959), tom 3 Wstępu do nauki o literaturze (1965); antologia Teoria badań literackich za granica (t. 1-2, 1965-1966), Mickiewicza „Historia przyszłości” i jej realizacje literackie (1964), W kręgu wielkich romantyków polskich (1966). Następnie trzy obszerne zbiory studiów historycznoliterackich, teoretycznych i teatrologicznych: Wokót teatru i literatury. Studia i szkice (1970), Pomiędzy historia a teoria literatury (1975), W orbicie literatury, teatru, kultury naukowej (1985).

A w międzyczasie tom Kierunki $w$ badaniach literackich. Od romantyzmu do połowy XX wieku (1984). I wreszcie kolejne tomy Teorii badań literackich za granica (t. 3-4, 1974; t. 5-6, 1986). Na koniec jeszcze dwie książki pod redakcją Pani Profesor: Tadeusza Hollendra, Liryka i satyra (1963; z udziałem prof. Bolesława W. Lewickiego) oraz „dokument” przewodniczenia Komisji Poetyki i Stylistyki Słowiańskiej MKS, czyli Poetyka i stylistyka słowiańska (1973).

$\mathrm{Tu}$ - przywołując te tytuły - chciałem uzmysłowić, jak ogromny dorobek ma na swoim koncie naukowo-badawczym Stefania Skwarczyńska. Trzeba powiedzieć, że oprócz wymienionych książek opublikowała ona parę setek rozpraw (znaczną część powtarzaja książki) w czasopismach i periodykach naukowych polskich i zagranicznych po polsku, ale i także w językach obcych, zwłaszcza francuskim i niemieckim, oraz w przekładach na inne języki. Prawdę mówiąc, nie umiałbym opisać i objaśnić czasu, rytmu oraz intensywności badawczej pracy pisarskiej Stefanii Skwarczyńskiej. Były okresy, w których ze względu na rozmaite formy współpracy 
w redakcji „Zagadnień Rodzajów Literackich”, Komisji Poetyki i Stylistyki Słowiańskiej i w związku z moimi obowiązkami asystenta i potem adiunkta, często bywałem w domu u Pani Profesor i - owszem - zawsze widziałem wkręcony w maszynę do pisania papier. Pani Profesor zawsze była obłożona książkami (pomagał w ich wydobywaniu ze zbiorów biblioteki uniwersyteckiej Pan Pułkownik - mąż), niekiedy dymił papieros w popielniczce, ale i tak trudno mi tę niezwykłą pracowitość sobie objaśnić. Bo przecież musiał znaleźć się też czas na dydaktykę, którą Pani Profesor traktowała z niezwykłą starannością, na wymogi administracyjno-urzędowe (przez cały okres uniwersytecki pełniła rozmaite funkcje na Wydziale Filologicznym i na uczelni, także w Łódzkim Towarzystwie Naukowym i w PAN). A ponadto dochodziły do tego regularne obowiazki korespondencyjne, czyli do końca życia wypełniane nadzwyczaj sumiennie i starannie powinności redaktora naczelnego „Zagadnień Rodzajów Literackich”, co wiązało się nie tylko z redagowaniem różnojęzycznych tekstów nadsyłanych do redakcji (która mieściła się wyłącznie w jej mieszkaniu jak już pisałem), lecz także $\mathrm{z}$ prowadzeniem $\mathrm{w}$ tych językach listowego dialogu z całym światem - od Japonii po Kanadę!

A przecież Pani Profesor opiekowała się bezustannie i rygorystycznie swoimi doktorantami nie tylko podczas seminariów, ale i podczas konsultacji domowych. $Z$ jej corocznych sprawozdań widać, jak nadzwyczaj często bywała powoływana na recenzenta rozpraw doktorskich i habilitacyjnych oraz wniosków profesorskich! Recenzje pisywała nie zwlekając, co przy takich okazjach zdarza się nierzadko. Obserwowałem osobiście, jak któregoś razu w gorączce i z grypa, leżąc w łóżku, $\mathrm{z}$ termometrem pod pachą, szkicowała tekst recenzji awansowej dla pewnego wrocławianina, autora rozpraw i książek o Witkacym (,,bo wiem - tłumaczyła - jakie to jest ważne dla jego pracy na uczelni").

Teksty naukowe Stefanii Skwarczyńskiej, zwłaszcza te w wydaniach książkowych, od samych lwowskich przedwojennych początków były dostrzegane i - by tak powiedzieć - regularnie recenzowane. W latach trzydziestych jej cztery książki doczekały się recenzyjnych opisów Mieczysława Giergielewicza, historyka i teoretyka literatury, dyrektora literackiego wydawnictwa Gebethner i Wolff, ale też Janiny Kulczyckiej, Manfreda Kridla, Zofii Szmydtowej, Karola Irzykowskiego, Piotra Grzegorczyka i Eugeniusza Sawrymowicza. Po drugiej wojnie dostrzegli jej prace Kazimierz Budzyk, Manfred Kridl (już w USA), Artur Hutnikiewicz i Juliusz Kleiner, ale dopiero po 1956 r. i zwłaszcza po powrocie Pani Profesor na Katedrę Teorii Literatury liczba wypowiedzi o jej dokonaniach i omówienia książek wyraźnie wzrosła. Pośród czytelników i recenzentów znajdujemy nazwiska Samuela Sandlera, Zdzisława Libery, Jarosława Iwaszkiewicza, Romana Taborskiego, Aliny Witkowskiej, Marii Jasińskiej, Zofii Stefanowskiej, Stanisława Witwickiego, Edwarda Balcerzana, Lecha Sokoła, Stanisława Dąbrowskiego, Henryka Markiewicza, Jana Trzynadlowskiego, Konrada Górskiego i Jerzego Starnawskiego. Pojawiają się też recenzje za granica - w Kanadzie i we Francji. Wzrasta ich liczba w latach siedemdziesiatych i osiemdziesiątych, choć pewnie nie tak, jak należałoby oczekiwać, biorąc pod uwagę rangę badań Pani Profesor.

Nigdy nie słyszałem jakichkolwiek jej komentarzy na ten temat. Raz, po publikacji książki Stanisława Dąbrowskiego Teoria genologiczna Stefanii Skwarczyńskiej. Próba analizy i krytyki (Gdańsk 1974), odważyłem się zapytać o ocenę tej obszernej 
pracy (liczacej 317 stronic!). Pani Profesor zrobiła minę, jakby pierwszy raz o niej usłyszała, więc nie bardzo wie, o co chodzi, i bez komentarza machnęła ręką. Do dziś nie wiem, co to miało znaczyć: czytała i miała do niej stosunek krytyczny, czy też dopiero ode mnie się dowiedziała, że takie dzieło istnieje...

Rok po śmierci Pani Profesor, z inicjatywy prof. Stanisława Kaszyńskiego, zorganizowaliśmy w łódzkim Instytucie Teorii Literatury, Teatru i Filmu sympozjum naukowe poświęcone jej twórczości naukowej. W jakiś czas potem wyszła książka Stefania Skwarczyńska - uczony, nauczyciel, wychowawca, z wypowiedziami uczestników sympozjum (zob. wykaz źródeł na końcu tego tekstu). Prof. Henryk Markiewicz, uczestnik sympozjum i autor jednego $z$ tekstów zawartych w książce, napisał:

Gdy dziś próbujemy ogarnąc i określić całość jej naukowego dorobku, pierwszym wrażeniem musi być podziw i onieśmielenie. Liczba publikacji Skwarczyńskiej sięga 500 pozycji. Jest to duża liczba, ale bynajmniej nie wyjątkowa. Pamiętać trzeba, że mieści się w tej liczbie aż 17 własnych książek. Najistotniejsze zaś to, że są wśród nich przedsięwzięcia fundamentalne, zakrojone $z$ wielkim rozmachem, a wykonane ze szczegółowością niezwykłą, nieraz przewyższające inne opracowania w swoim rodzaju. Nie zawsze zdajemy sobie sprawę, że Wstęp do nauki o literaturze, prawda, że nie zakończony, ale [...] mieści w sobie niemal całość teorii dzieła literackiego [...], a tom III wytrzymuje do dziś porównanie z innymi opracowaniami ogólnych problemów genologii. Daleko pozostawia za sobą zagraniczne ujęcia systematyka głównych kierunków badań literackich [...]. Osiagnnięcia te tym bardziej należy podziwiać, że dokonane zostały na rozległych obszarach humanistyki i wielokrotnie mają walor naukowego pionierstwa. Była przede wszystkim teoretykiem literatury, dokładniej można powiedzieć - chronologicznie pierwszym polskim uczonym skoncentrowanym przede wszystkim na teorii literatury. Zainicjowała również badania nad historią kierunków literaturoznawczych [...]. Uprawiała również nowoczesną komparatystykę [...]. Ale i w dziedzinach tradycyjnie uprawianych penetrowała Skwarczyńska nowe problemy i tematy. [...] Nowatorskie cechy miała przede wszystkim koncepcja literatury ogarniająca wszelkiego typu sensowne wypowiedzenia językowe.

Te charakterystyki dopełniają i inni autorzy książki: Irena Sławińska podsumowuje osiagnięcia badawcze Pani Profesor w zakresie historii i teorii dramatu i teatru, a Maria Janion - studia z zakresu „wewnętrznej historii poezji polskiej”, stwarzające „metodologie badań nad obrazem literackim”. Tu tylko jedna uwaga: nie przyznamy dzisiaj racji Sławińskiej, która większość swego tekstu poświęciła krytycznej polemice $z$ teatralną teoria dramatu Skwarczyńskiej. Po 30 latach od czasu, gdy powstał tekst Sławińskiej, najwyraźniej widzimy - obserwując dominujące współcześnie praktyki inscenizacyjne, estetykę współczesnego teatru i poszukiwania twórcze artystów teatru - że we wszystkich polemikach i sporach rację miała właśnie Stefania Skwarczyńska, choć wtedy była raczej osamotniona w swoich badawczych stwierdzeniach, iż miejsce dramatu jest nie w obszarach literatury, ale wśród sztuk wielotworzywowych.

Łódź, styczeń 2020

\section{Źródła}

S. S kw a r c zy ń s k a, Hollender Tadeusz (1910-1943). Hasło w: Polski słownik biograficzny. T. 9. Wrocław 1960.

M. J a sińska, Stefania Skwarczyńska jako teoretyk literatury. „Prace Polonistyczne” seria 20 (1964). 
W. Li pi e c, Problematyka dramatu $w$ pracach Stefanii Skwarczyńskiej. Jw.

Stefania Skwarczyńska. Hasło w: Stownik wspótczesnych pisarzy polskich. Oprac. E. Korzeniews ka [i in.]. T. 3. Warszawa 1964.

S. Dąb row ski, Teoria genologiczna Stefanii Skwarczyńskiej. Próba analizy i krytyki. Gdańsk 1974.

B. W. Lewicki, Wiesz, jak jest. Łódź 1974.

K. B a ran ows ki, Oddziat Wolnej Wszechnicy $w$ Łodzi 1928-1939. Warszawa 1977.

A. Klu b a - Poła ty ń s k a, A. S o r bj a n, Dokumentacja twórczości naukowej Stefanii Skwarczyńskiej. Red. S. Ka szyń ski. Łódź 1984.

S. S k w a r c zy ń s k a, Łódzki dwumiesięcznik „Zagadnienia Literackie”, dawniej „Życie Literackie” (1946-1948) w stużbie teorii literatury. W: W orbicie literatury, teatru, kultury naukowej. Warszawa 1985.

S. Skwarczyńska, U źródeł autobiografii naukowej. „Kwartalnik Historii Nauki i Techniki” 1987, nr 2.

Stefania Skwarczyńska - szkic do portretu uczonej. Film dokumentalny. Reż. Z. Sk on ie c zny. Wytwórnia Filmów Oświatowych i Programów Edukacyjnych, 1988.

O. Wa tow a, Wszystko, co najważniejsze... Warszawa 1990.

E. N u r c zy ń s k a - F i d el s k a, B. St o la r s k a, Bolesław Włodzimierz Lewicki. Bibliografia. Łódź 1991.

M. Tyrowicz, Wspomnienia o życiu kulturalnym i obyczajowym Lwowa 1918-1939. Przedm. J. Maślanka. Wrocław 1991.

J. W ę g i e r s ki, Lwów pod okupacją sowiecką 1939-1941. Warszawa 1991.

Stefania Skwarczyńska - uczony, nauczyciel, wychowawca. Red. M. Biela cki, J. Trzynadlow s ki. Łódź 1992. (Zawartość: J. Tr zy n a d low s ki, wstęp; Stefania Skwarczyńska jako badacz, nauczyciel, przyjaciel. - H. M a r k i e w i c z, Stefania Skwarczyńska. Sylwetka naukowa. - I. Sła w ińsk a, Problematyka dramatu w pracach Stefanii Skwarczyńskiej. - A. Ku li g o w s k a, Stefania Skwarczyńska jako historyk teatru. - T. C i e śl i k o w s k a, Teoria literatury Stefanii Skwarczyńskiej. - M. J an i o n, Stefania Skwarczyńska i obrazy poetyckie. - K. Ku p is z, Stefanii Skwarczyńskiej francuskie powinowactwa z wyboru. - W. Ostrowski, Stownik rodzajów literackich $w$ zamierzeniu Stefanii Skwarczyńskiej. - G. Gazda, Stefania Skwarczyńska jako redaktor i wydawca. - M. Pét e r, Głos wegierskiego przyjaciela).

S. Skw a r c zy ń s ka, Byłam niepodległa. Oprac., podał do druku G. G a zd a. „Gazeta Wyborcza” („Verte”), wyd. łódzkie, 1993, nr 99.

E. Nu r czyńska-Fidelska, B. St ol a rska, Biografia twórcza Bolesława Włodzimierza Lewickiego. W: B. W. Le w i c ki, O filmie. Wybór pism. Wybór, wstęp, red. E. Nu r c zy ń s k a - F i de ls ka, B. Stolarska. Łódź 1995.

J. St a rn a w ski, Sylwetki lwowskich historyków literatury. Łódź 1997.

H. Pust k ow ski, Skwarczyńska Stefania. Hasło w: Polski słownik biograficzny. T. 38, z. 159. Warszawa-Kraków 1998.

Profesor Stefania Skwarczyńska. Red. J. Śló s a r s k a. Łódź 1998.

G. G a zd a, O szkole naukowej Stefanii Skwarczyńskiej. W zb.: Rola nauczycieli tódzkich $w$ tworzeniu dziedzictwa kulturowego Łodzi. Red. S. G a la. Łódź 1998.

J. Su ch miel, Działalność naukowa kobiet w Uniwersytecie we Lwowie do roku 1939. Częstochowa 2000.

Stefania Skwarczyńska. Hasło w: Współcześni polscy pisarze i badacze literatury. Stownik biobibliograficzny. Red. J. Czach owska, A. Szałagan [i in.]. T. 8. Warszawa 2001.

G. G a zd a, Skwarczyńska Stefania. Hasło w: Britannica. Edycja polska. Poznań 2004.

Historia i trwanie. 60 lat Katedry Teorii Literatury - Instytutu Teorii Literatury, Teatru i Sztuk Audiowizualnych Uniwersytetu Łódzkiego (1945-2005). Red. G. G a z d a. Łódź 2005 (wyd. 2: 2007).

E. Hli b, Moje chodzenie po Lwowie i okolicy. Cz. 2: Zagłada Żydów lwowskich. Wrocław 2006.

W. Szolg in ia, Tamten Lwów. T. 1: Oblicze miasta. Kraków 2010.

G. G a zd a, Stefania Skwarczyńska i teatr. W zb.: Portrety teatralne piórkiem-węglem-pędzlem. Prace dedykowane profesor Annie Kuligowskiej-Korzeniewskiej. Red. I. J aj t e - Le w k o w i c z, M. L e yko, przy współpr. D. Leśni kows kiego. Łódź 2011.

A. B i ed r zy c k a, Kalendarium Lwowa 1918-1939. Kraków 2012.

M. Golicka-Jabłońska, Tak trzeba. Łódź 2013. 
Oblicza slawistyki. Komisje Międzynarodowego Komitetu Slawistów (1958-2013). Red. S. G a j d a. Opole 2013.

Ż. Sło n i ow s ka, Przedwojenny Lwów. Najpiękniejsze fotografie. Warszawa 2013.

R. J. Czarnow s ki, E. W oj d e c ki, Lwów. Dzieje miasta. Kielce 2015.

M. Ch r o s tek, Złote lata polonistyki lwowskiej (1919-1939). Rzeszów 2016.

G. G a z d a, Fragmenty autobiografii. W zb.: Moja droga do nauki. Red. M. P a w li k. Łódź 2016.

G. Gazd a, „Avec le temps...” Łódź 2017.

A. Franaszek, Herbert. Biografia. T. 1-2. Kraków 2018.

M. U rb a n e k, Profesor Weigl i karmiciele wszy. Warszawa 2018.

G. G a u d e n, Lwów - kres iluzji. Opowieść o pogromie listopadowym 1918. Wyd. 2, popr. Kraków 2019.

L. C. Kleve ma n, Lwów. Portret utraconego miasta. Przeł. D. Guzi k. Kraków 2019.

K. Kutz, Będzie skandal. Autoportret. Współpr. R. Si e wi o r e k. Kraków 2019.

D. K. Markows ki, Dwa powstania. Bitwa o Lwów 1918. Kraków 2019.

T. Ols z ańs ki, Kresy Kresów. Stanisławów jednak żyje. Kraków 2019.

Abstract

GRZEGORZ GAZDA University of Łódź

\section{PROFESSOR STEFANIA SKWARCZYŃSKA AN ATTEMPT AT SUBJECTIVE BIOGRAPHY}

The paper is constructed from three partially concurrent parts, namely from a biography of Stefania Skwarczyńska-a distinguished literary theoretician and historian, then from history of Chair of Literary Theory, University of Łódź, which in the year 2020 celebrated its $75^{\text {th }}$ anniversary, and ultimately from the life of Grzegorz Gazda, Skwarczyńska's close co-worker, continuator of the many of her research and editorial initiatives. The sketch documents Skwarczyńska's achievements and those of her alumni and students, making indebted gratitude of memory the main source of knowledge. 